\title{
A Decision Support Model for Measuring Technological Progress and Productivity Growth: The Case of Commercial Banks in Vietnam
}

\author{
Chia-Nan Wang ${ }^{1, *(\mathbb{D})}$, Ngoc-Ai-Thy Nguyen ${ }^{1, * \mathbb{D}}$, Thanh-Tuan Dang ${ }^{1,2, * \mathbb{D}}$ and Thi-Thuy-Quynh Trinh ${ }^{1}$ (D) \\ 1 Department of Industrial Engineering and Management, National Kaohsiung University of Science and \\ Technology, Kaohsiung 80778, Taiwan; f108143135@nkust.edu.tw \\ 2 Department of Logistics and Supply Chain Management, Hong Bang International University, \\ Ho Chi Minh 723000, Vietnam \\ * Correspondence: cn.wang@nkust.edu.tw (C.-N.W.); thy.logistics@gmail.com (N.-A.-T.N.); \\ tuandang.ise@gmail.com (T.-T.D.)
}

check for updates

Citation: Wang, C.-N.; Nguyen, N.-A.-T.; Dang, T.-T.; Trinh, T.-T.-Q. A Decision Support Model for Measuring Technological Progress and Productivity Growth: The Case of Commercial Banks in Vietnam. Axioms 2021, 10, 131. https:// doi.org/10.3390/axioms10030131

Academic Editor: Faith-Michael E. Uzoka

Received: 18 May 2021

Accepted: 22 June 2021

Published: 24 June 2021

Publisher's Note: MDPI stays neutral with regard to jurisdictional claims in published maps and institutional affiliations.

Copyright: (c) 2021 by the authors. Licensee MDPI, Basel, Switzerland. This article is an open access article distributed under the terms and conditions of the Creative Commons Attribution (CC BY) license (https:/ / creativecommons.org/licenses/by/ $4.0 /)$.

\begin{abstract}
The interactive relationship between the banking system and enterprise makes up the role that affects a national economy. Significantly, the relationship between banking and technology has become tighter over the past few decades. An assessment of bank performance is critical for understanding their position and provides valuable information to practitioners. In this paper, we assess the performance of the top 18 commercial banks in Vietnam during 2015-2019. The assessment utilizes two data envelopment analysis (DEA) models while involving the banks' performance in six dimensions, including assets, deposits, operating expenses, liabilities as inputs, while treating loans and net income as outputs. Using the Malmquist measurement, the total productivity growth indexes of the banks are obtained, which are decomposed into technical and technological evolutions. Window analysis is used to compute the efficiencies of the banks in every single year in 2015-2019. From the results of Malmquist, most banks are found to decrease their Malmquist productivity indexes from 2015 to 2019, wherein both of their technical and technological indexes declined. Window analysis indicates B6-SHBank, B1-Vietinbank, and B18-PetrolimexGroup as the most efficient banks during 2015-2019, and in the interim, B16-BaoVietBank, B11-NationalCitizen, and B13-VietnamMaritime ranked on the bottom line. The managerial implications of this research help to reflect the comprehensive insights of the top Vietnamese commercial bank performance and offer a strategic guideline for decision-makers toward sustainable development in the banking industry.
\end{abstract}

Keywords: data envelopment analysis; technological progress; productivity growth; commercial bank; decision analysis

MSC: 90B50; 62-07; 62P20; 91B06; 68M20

\section{Introduction}

In response to the impacts of the COVID-19 crisis and the global economic recession, countries are looking to give their economies a much-needed jolt. In this context, financial assistance and supportive policies are implemented via economic stimulus packages to protect enterprises and citizens. The banking sector is a hinge for almost all economic activity. While the banking sector will be negatively affected by the crisis, it is also critical for national economic recovery. Amid this turbulence, the role of banks has been highlighted in recent periods, with the understandable assumption that they will step up to provide financial assistance, not just supporting customers and employees, but society as well.

The Vietnamese banking industry has also witnessed the apparent impact of the COVID-19 crisis. The banking sector was forecasted to have $\$ 39.85$ billion in debts that were not able to be paid as scheduled due to the effect of COVID-19. The General Department of Statistics reported that the banking system's credit growth was 0.68 percent in the first 
quarter of 2019 [1]. This growth rate was held at the lowest from the 2015 to the 2019 period, ranging from $1.25 \%$ to $2.81 \%$. For consumer credit, the influence of the COVID-19 would take place in two stages. Since late March 2020, the existing and new loans' interest rates were decreased by $2 \%$. The banks rescheduled debt to support firms' survival through the crisis [2]. Banks are improving customer service levels and significantly contributing to the GDP annually. However, the financial experts predicted that most banks would decrease deposit rates and interest rates, rescheduling debt payments as an effect of the crisis. The Vietnamese commercial banking system performs a crucial function in providing credit to enterprises. Therefore, the sustainability development of the Vietnamese banking sector is pivotal to the national economy [3].

In parallel, understanding the major determinants of bank performance during financial crises is crucial for tailoring public policies, regulations, and management practices to recognize and prevent bank problems early. In this context, Assaf et al. [4] indicated in the study that an overlooked factor affecting bank performance during crises is bank efficiency in pre-crisis times. Thus, aiming to estimate bank efficiency, which is used subsequently in panel estimations of the effects of bank efficiency on bank performance, in this paper, we use DEA Malmquist and Window models to study the intertemporal performance of top commercial banks in Vietnam in 2015-2019. To achieve this objective, we decompose the banks' performance into six aspects, i.e., loans, net income, assets, deposits, operating expenses, and liabilities. To support the involvement of these variables, various related indexes and rankings by experts, researchers, and recent studies in the bank industry were investigated (elaborated in Section 3.2.1). The selection of these dimensions was also based on data obtained from the Vietnam Stock Market database, a reliable website for searching information and data using investment tools and analyzing stocks online to help investors get an insight into market and investment decisions. The operation of banks involves the utilization of resources in multiple dimensions such as assets, deposits, operating expenses, and liabilities (input variables) and generates different types of outputs such as loans and net income. Thus, the evaluation must consider multiple inputs and outputs simultaneously. Moreover, a bank naturally operates as a complex process, and thus the relationship between inputs and outputs has no readily available analytical representation. For these concerns, the data envelopment analysis (DEA) is a suitable approach to assist in this assessment. The adoption of DEA models for bank performance measurements is an active research area [5-9]. From researchers' and practitioners' perspectives, DEA can uncover the pattern of efficiency change over time for each bank. The approach is also able to indicate inefficient banks which must be improved further and those banks to be role models for other banks.

We applied the Malmquist index measurement and the Window analysis in DEA to a sample of 18 commercial banks in Vietnam during 2015-2019. We separated the six dimensions into four inputs (assets, deposits, operating expenses, and liabilities) and two outputs (loans and net income) to assess the performance of the banks. The Malmquist model is used to capture the total productivity growth rates of the banks, which discerns the pattern of efficiency change over time. To pin down the cause of efficiency change, we decomposed the banks' Malmquist indexes into a technical efficiency change (catch-up) and a technological change (frontier-shift), which reflects an individual bank's evolution driven by its efforts and the entire group's change driven by prevalent trends. The Window analysis is employed to compute the overall efficiency performance of the banks in every single year during 2015-2019. By using this model, this research takes all six dimensions into account to benchmark the banks' performance relative to an efficiency frontier. As far as it is known, the performance evaluation of banks' efficiency at financial indicators, focusing on two pictures of the evaluation process, which are productivity improvement and efficiency performance, has not been widely studied in Vietnam. This research aims to partially fill the gaps found in the existing literature. By using the proposed DEA models, a more robust and comprehensive insight into the Vietnamese banking businesses is provided that can serve as a viable guideline for practitioners to be more aware of 
their position and situation, in light of devising more effective strategies in efficiency improvement, aiming towards sustainable development in the banking industry.

The rest of the paper is organized as follows. The literature review of relevant previous studies is presented in Section 2. Section 3 explains the methodology approach and study materials. Following that, Section 4 details the case study of Vietnam. Results analysis is provided in Section 5, and Section 6 displays discussions and conclusions.

\section{Literature Review}

In the management science of efficiency assessment literature, discussing banking performance has been a consistent major concern. Various approaches have been considered in the literature. Concerning the issue in Vietnam, Dang-Thanh [9] utilized a modified DEA window analysis to investigate the Vietnamese banking performance changes from 1990 to 2010. Cuong et al. [10] used the combing model of Fuzzy the Technique for Order of Preference by Similarity to Ideal Solution (FTOPSIS) and the Fuzzy Analytical Hierarchy Process (FAHP) to examine and rank five commercial banks in Vietnam. For other countries and purposes, Tlig et al. [11] applied the two approaches of fuzzy data envelopment analysis in evaluating Tunisian commercial banking performance based on certain crisp and imprecise data. In terms of the aspects considered in the banking assessment, relevant studies investigated the impacts of these following factors: cost and profit efficiency [4], interest expense, operating expense, interest/non-interest revenue, and loans [12], more complex dimensions such as service quality [13] and systemic risk [14], to mention a few. Considering complicated dimensions, the use of Game Theory as a mandatory feature in banking sectors is the only method used to ensure a competitive advantage in the triangle of Customer-Competitors-Product and Service. According to Game Theory assumptions, if a zero-sum game is used, one party's profit will result in the loss of the other; as a result, banks will face severe and perfect competition, even if they have an oligopolistic structure [15]. Game theory approaches are useful and have been a popular mathematical framework developed to address problems in corporate finance, portfolio management, and investment banking, as carried out in various studies [15-19].

Given a handful of methodologies used in efficiency measurements, DEA is a popular nonparametric assessment approach for relative efficiency and productivity across different regions or time periods based on mathematical programming for benchmarking multiinput and multi-output units. Many forms of DEA have been widely applied to assess the performance of various entities, including countries, cities, industrial sectors, facilities, and companies. For example, Wang et al. [20] introduced a variegated approach by connecting the grey model GM and DEA Window model to approach the efficiency of 16 primary Asia airline organizations. Another study by Wang et al. [21] also used the DEA and Grey model to estimate twenty-four ITC companies of Vietnam's performance. Novickyte et al. [22] evaluated the performance of the banks in Lithuania and examined bank efficiency in a low-interest-rate environment. Xu et al. [23] used DEA to recommend a framework to estimate the efficiency of securities companies which concerned technical heterogeneity and operational risks. The eco-productivity of 17 European countries was estimated by the Slacks-based measure method by Wang et al. [24] Liu et al. [25] evaluated the efficiency of Taiwanese semiconductor packaging and testing companies from 2000 to 2003. Estache et al. [26] used the Malmquist index method to examine and calculate and disintegrate the innovation efficiency of Mexico's port system based on infrastructure from 11 main ports from 1996 to 1999. Another application of the Malmquist model showed the efficiency development of the Norwegian Motor Vehicle Inspection Agencies from 1989 to 1991 period. In the study, Odeck et al. [27] calculated the efficiency by DEA and productivity by the Malmquist index. Another study by Huang et al. [28] applied the combination of the DEA Malmquist model and the spatial panel method to discover the role of technological progress in reducing China's energy concentration. Besides, the Window model in DEA has widely applied in recent research. Chung et al. [29] recommended a solution for long-term effectiveness in productivity and interest gaining. Combining artificial neural 
networks with the DEA approach, Vlontzos et al. [30] assessed and forecast the greenhouse gas emissions from EU countries' agricultural production. Halkos et al. [31] combined generalized methods of moments (GMM) estimators and DEA to measure the Kuznets curve of countries' environmental performance and national revenue. Řepková et al. [32] measured the performance of the Czech banking sector from 2003 to 2012. For assessing the Vietnamese textile and apparel industry, Le and Wang [33] propose an integrated approach using grey prediction-Malmquist-window analysis. The main purpose of this study was to provide an empirical analysis for enterprises by foreseeing future values, measuring the productivity growth of industrial sectors and further detecting the performance trends of companies.

This study aims to utilize two effective DEA models which are the Malmquist model and the Window model to construct a complete and viable evaluation framework devoted to the banking industry's sustainable development. The practical contribution of this study is the comprehensive insight contributed by solving the case study of 18 commercial banks in Vietnam. Based on the selected indicators, the productivity growth of banks over time is measured by the Malmquist model, consisting of performance change, technological change, and total productivity change. The Window model then computes the efficiency of banking institutes' performance, including variation by term, window length of the whole period, and window length of three years. The managerial contribution of this study is to support the decision-makers to be aware of their organization's position in the banking industry to apprehend overall efficiency and productivity. This quantitative method also provides an intensive guideline in the decision-making process with other competitors in the related industries and anywhere else in the world.

\section{Materials and Methods}

\subsection{Research Methodology}

The mathematical modeling is applied for measuring the productivity growth, and the Window model is used for ranking the performance in the banking industry. Besides, a case study of the top 18 commercial banks in Vietnam is included. The research methodology is detailed as follows.

Part 1. Research direction: The first part defines the problem in the banking industry while determining the research objective, implementing a literature review to understand relevant previous studies, and building the modeling framework. The research objective is to measure the productivity growth for the period from 2015 to 2019 and to rank the performance of the top 18 commercial banks in Vietnam through a proposed quantitative method. The research is expected to provide an intensive guideline to decision-makers in relevant industries, to support them not only in order to improve their internal performance, but also to consider external competitiveness. Besides a practical contribution, the study is expected to minimize the impact of the global pandemic (i.e., COVID-19) on Vietnam's banking industry.

Part 2. Research analysis: The selected variables are a critical step before applying the two models in the DEA approach, the Malmquist and Window model in this research. This selection significantly affects the process of the model's calculation. The number of DMUs is at least twice the total number of inputs and outputs [34]. The paper's objective is to evaluate the productivity growth and rank the performance position in the banking industry. Hence, according to the financial indicators in the banking management, the proper factors are carefully considered. Four inputs, which are assets, deposits, operating expenses, and liabilities, are selected; moreover, two output factors are loan and net income. Moreover, the correlation relationship among inputs and outputs are tested using Pearson theory before applying these DEA models.

Part 3. Research discussion: In this part, the results of the research will be discussed to meet the research objective. The results of the research are to provide a framework of the mathematical modeling for measuring and ranking the efficiency of the bank's operation. 
Besides, a case study of the top 18 commercial banks in Vietnam is applied to demonstrate the model's effectiveness. Future research is also given in this part.

\subsection{Mathematical Modeling Approach}

\subsubsection{Modeling Framework}

Generally, the modeling framework of the research for measuring the productivity growth and ranking the performance of DMUs (i.e., 18 commercial banks in Vietnam), a case study with four inputs and two outputs is presented in Figure 1.

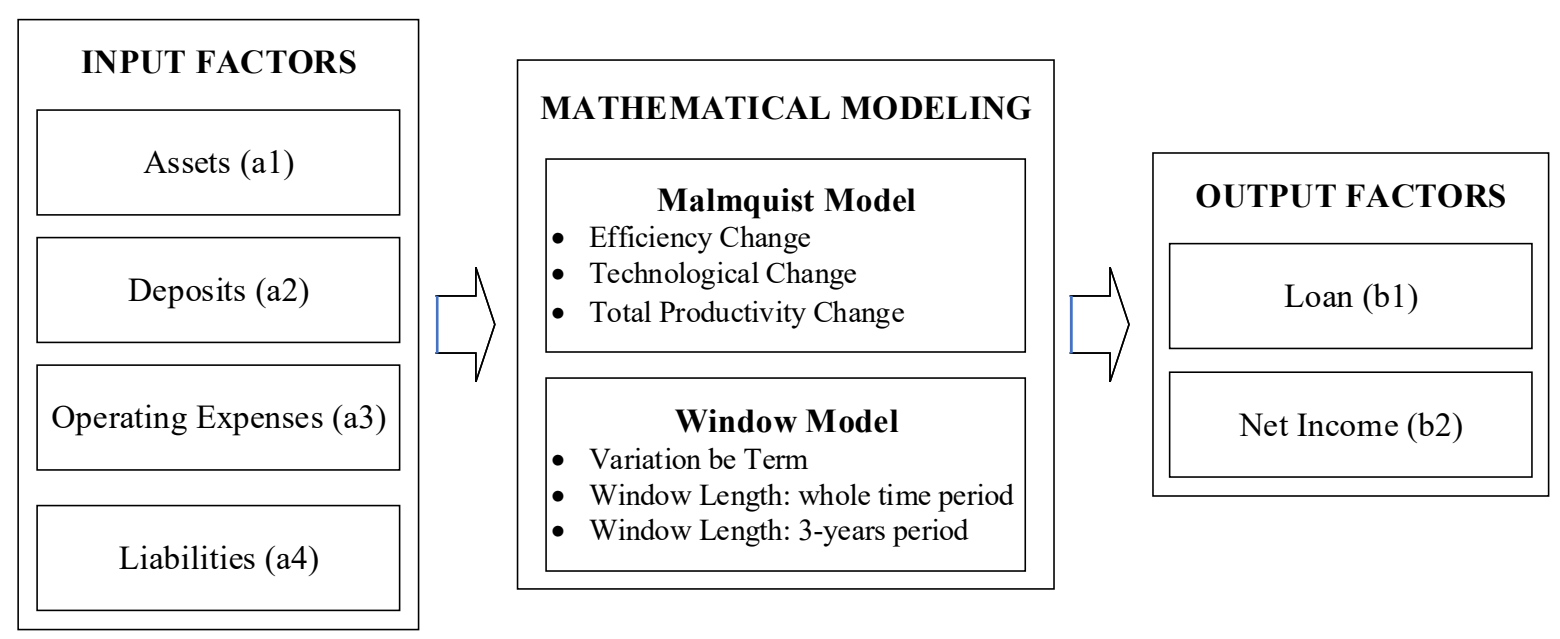

Figure 1. The modeling framework of the research.

The mathematical modeling consists of two sub-DEA models, which are the Malmquist model, and the Window model. The Malmquist model is used for measuring the productivity growth of banks between two periods based on three indexes, including technical efficiency change, technological change, and total productivity change. In the interim, the Window model is used for ranking the performance of banks over multiple periods, including variation by term, window length of the whole time period, and window length of a 3-year period. Therefore, the research applied this framework to accomplish the paper's objective.

DEA is a complex method in which the inputs and outputs have a significance on the outcome. According to previous investigations, it is found that the business needs to adjust or reduce inputs while improving or increasing outputs, which are financial indexes $[35,36]$. Based on the objective of the study and the list of common input and output factors in the performance evaluation of banking systems (Table 1), this paper considers four inputs and two outputs, which are described as follows.

Input factors:

1. Assets (a1): the amount of the total assets maintained by the bank that can be sold for value (i.e., belongings, interchange assets, customer's loans, deposits to the headquarter).

2. Deposits (a2): the total amount of deposits from customers and other banks.

3. Operating expenses (a3): expenditure incurred by banking firms (i.e., employee compensation and benefits, information technology, legal fees).

4. Liabilities (a4): a commitment that must eventually be paid (i.e., loans from the headquarter, customer's deposits, interchange liabilities, non-performing loans).

Output factors:

5. Loan (b1): referred to as a lending of money by customers, business, or company. It reflects the ability to provide financial services.

6. Net Income (b2): refer to net interest income of the bank, is calculated by the interest payment on assets minus the interest payment on liabilities. 
Table 1. List of common input and output factors used in previous studies.

\begin{tabular}{|c|c|c|c|c|c|}
\hline No. & $\begin{array}{l}\text { Authors } \\
\text { [Citation] }\end{array}$ & Input Factors & Output Factors & \# of DMUs & Research Scopes \\
\hline 1 & $\begin{array}{l}\text { Jablonsky et al., } \\
\text { (2004) [37] }\end{array}$ & $\begin{array}{l}\text { Employees } \\
\text { Operating expense } \\
\text { Space }\end{array}$ & $\begin{array}{l}\text { Number of accounts } \\
\text { Number of } \\
\text { transactions } \\
\text { Savings }\end{array}$ & 81 & $\begin{array}{l}\text { Reflecting the productive } \\
\text { efficiency of the branches in } \\
\text { Czech Republic }\end{array}$ \\
\hline 2 & $\begin{array}{l}\text { Emrouznejad } \\
\text { and Anouze, } \\
(2010)[38]\end{array}$ & $\begin{array}{l}\text { Assets } \\
\text { Equity } \\
\text { Deposit }\end{array}$ & $\begin{array}{l}\text { Loan } \\
\text { Profit }\end{array}$ & 36 & $\begin{array}{l}\text { Assessing the efficiency and } \\
\text { productivity of the banking sector } \\
\text { in the Gulf Cooperation Council } \\
\text { countries }\end{array}$ \\
\hline 3 & $\begin{array}{l}\text { Lin and Chiu, } \\
\text { (2013) [39] }\end{array}$ & $\begin{array}{c}\text { Fixed assets } \\
\text { Operating expense } \\
\text { Capital }\end{array}$ & $\begin{array}{l}\text { Non-interest income } \\
\text { Interest income } \\
\text { Profit }\end{array}$ & 30 & $\begin{array}{c}\text { Investigating performance } \\
\text { evaluation for the Taiwanese } \\
\text { domestic banks }\end{array}$ \\
\hline 4 & $\begin{array}{l}\text { Fujii et al., (2014) } \\
\text { [40] }\end{array}$ & $\begin{array}{l}\text { Employees } \\
\text { Deposits } \\
\text { Fixed assets }\end{array}$ & $\begin{array}{l}\text { Acquired assets } \\
\text { Customer loans } \\
\text { Bad loans }\end{array}$ & 24 & $\begin{array}{l}\text { Examining technical efficiency } \\
\text { and productivity growth in the } \\
\text { Indian banking sector }\end{array}$ \\
\hline 5 & $\begin{array}{l}\text { Wang et al., } \\
(2014)[41]\end{array}$ & $\begin{array}{l}\text { Employees } \\
\text { Fixed assets }\end{array}$ & $\begin{array}{l}\text { Non-interest income } \\
\text { Interest income } \\
\text { Non-performing loans }\end{array}$ & 16 & $\begin{array}{l}\text { Measuring efficiency of the } \\
\text { Chinese commercial banking } \\
\text { system }\end{array}$ \\
\hline 6 & $\begin{array}{l}\text { Wanke et al., } \\
\text { (2016) [42] }\end{array}$ & $\begin{array}{l}\text { Total costs } \\
\text { Employee costs }\end{array}$ & $\begin{array}{l}\text { Total deposits } \\
\text { Income before tax } \\
\text { Total credit }\end{array}$ & 117 & $\begin{array}{c}\text { Assessing productive efficiency of } \\
\text { Mozambican banks }\end{array}$ \\
\hline 7 & $\begin{array}{l}\text { Mahmoudabadi } \\
\text { and } \\
\text { Emrouznejad, } \\
\text { (2019) [43] }\end{array}$ & $\begin{array}{l}\text { Employees } \\
\text { Fixed assets } \\
\text { Non-operating costs } \\
\text { Interest expenses }\end{array}$ & $\begin{array}{l}\text { Bank facilities } \\
\text { Interest income } \\
\text { Non-interest income }\end{array}$ & 37 & $\begin{array}{c}\text { Evaluating operational efficiency, } \\
\text { service effectiveness, and social } \\
\text { effectiveness of commercial banks } \\
\text { in Iran }\end{array}$ \\
\hline 8 & $\begin{array}{l}\text { Yu et al., (2021) } \\
\text { [44] }\end{array}$ & $\begin{array}{c}\text { Fixed assets } \\
\text { Labor } \\
\text { Operating expenses }\end{array}$ & $\begin{array}{l}\text { Loan } \\
\text { Securities investment } \\
\text { Non-interest income }\end{array}$ & 22 & $\begin{array}{l}\text { Measuring Taiwanese bank } \\
\text { performance }\end{array}$ \\
\hline 9 & $\begin{array}{l}\text { Sáez-Fernández } \\
\text { et al., (2021) [45] }\end{array}$ & $\begin{array}{c}\text { Staff expenses } \\
\text { Non-earning assets } \\
\text { Equity } \\
\text { Customer deposits } \\
\text { Market liabilities }\end{array}$ & $\begin{array}{l}\text { Loan } \\
\text { Securities }\end{array}$ & 124 & $\begin{array}{l}\text { Assessing the technical } \\
\text { performance of Brazilian banks }\end{array}$ \\
\hline 10 & This paper & $\begin{array}{c}\text { Assets } \\
\text { Deposits } \\
\text { Operating expenses } \\
\text { Liabilities }\end{array}$ & $\begin{array}{l}\text { Loan } \\
\text { Net income }\end{array}$ & 18 & $\begin{array}{l}\text { Measuring technological and } \\
\text { productivity growth of } \\
\text { commercial banks in Vietnam }\end{array}$ \\
\hline
\end{tabular}

Source: defined by the authors.

\subsubsection{Pearson Correlation}

The Pearson is generally used in previous studies, which describes the linear relationship of two variables, where +1 presents a total positive linear, 0 presents no linear, and -1 presents a total negative linear [33].

Isotropic is an essential DEA data assumption. The relationship between inputs and outputs will be verified before using the DEA model, which means that it should be in a total positive linear relationship. Pearson's formula $(r)$ of two factors $(u)$ and $(v)$ is calculated as Equation (1) [46].

$$
r_{u v}=\frac{\sum_{i=1}^{n} u_{i} v_{i}-\frac{\sum_{i=1}^{n} u_{i} \sum_{i=1}^{n} v_{i}}{n}}{\sqrt{\left(\sum_{i=1}^{n} u_{i}{ }^{2}-\frac{\left(\sum_{i=1}^{n} u_{i}\right)^{2}}{n}\right)\left(\sum_{i=1}^{n} v_{i}^{2}-\frac{\left(\sum_{i=1}^{n} v_{i}\right)^{2}}{n}\right)}}
$$


where $n$ represents sample size; $u_{i}, v_{i}$ are the positions of a particular sample related to $i$.

\subsubsection{DEA Malmquist Model}

The catch-up index (C), i.e., technical efficiency, frontier-shift index (F), i.e., technological, and Malmquist Productivity Indicator (MPI), are computed as Equations (2)-(5) [47].

$$
\begin{gathered}
C=\frac{d^{2}\left(\left(u_{i}, v_{i}\right)^{2}\right)}{d^{1}\left(\left(u_{i}, v_{i}\right)^{1}\right)} \\
F=\left[\frac{d^{1}\left(\left(u_{i}, v_{i}\right)^{1}\right)}{d^{2}\left(\left(u_{i}, v_{i}\right)^{1}\right)} \times \frac{d^{1}\left(\left(u_{i}, v_{i}\right)^{2}\right)}{d^{2}\left(\left(u_{i}, v_{i}\right)^{2}\right)}\right]^{\frac{1}{2}} \\
M P I=C \times F=\frac{d^{2}\left(\left(u_{i}, v_{i}\right)^{2}\right)}{d^{1}\left(\left(u_{i}, v_{i}\right)^{1}\right)} \times\left[\frac{d^{1}\left(\left(u_{i}, v_{i}\right)^{1}\right)}{d^{2}\left(\left(u_{i}, v_{i}\right)^{1}\right)} \times \frac{d^{1}\left(\left(u_{i}, v_{i}\right)^{2}\right)}{d^{2}\left(\left(u_{i}, v_{i}\right)^{2}\right)}\right]^{\frac{1}{2}} \\
M P I=\left[\frac{d^{1}\left(\left(u_{i}, v_{i}\right)^{2}\right)}{d^{1}\left(\left(u_{i}, v_{i}\right)^{1}\right)} \times \frac{d^{2}\left(\left(u_{i}, v_{i}\right)^{2}\right)}{d^{2}\left(\left(u_{i}, v_{i}\right)^{1}\right)}\right]^{\frac{1}{2}}
\end{gathered}
$$

where $\left(u_{i}^{1}, v_{i}^{1}\right)$ denotes $\mathrm{DMU}_{\mathrm{i}}$ at stage $1,\left(u_{i}^{2}, v_{i}^{2}\right)$ denotes $\mathrm{DMU}_{\mathrm{i}}$ at stage 2 , and the efficiency score of the $\mathrm{DMU}_{\mathrm{i}}\left(u_{i}^{1}, v_{i}^{1}\right)^{t_{1}}$ is measured by the technological frontier $t_{2}: d^{t_{2}}\left(\left(u_{i}, v_{i}\right)^{t_{1}}\right)$.

It can be seen from the above equations that the indexes of catch-up, frontier-shift, and Malmquist productivity of $\mathrm{DMU}_{\mathrm{i}}$ from stage 1 to 2 achieved progress, stable, or regress when the value of catch-up, frontier-shift, and Malmquist productivity is greater than 1, equal to 1 , or less than 1 , separately.

\subsubsection{DEA Window Model}

Charnes et al. $[35,48]$ developed the Window model from DEA. The method objective is to measure the trend (i.e., efficiency) of DMUs over a long period with numerous input and output factors in the window length. Window investigation shows how the efficiency is implemented by sequences of overlapping windows. The DEA window approach is described briefly as follows. If $D M U_{n}$ ( $N$ is the whole DMUs; $n=1 \div N$ ) represents the $n$-th DMU that has $\mathrm{m}$ input variables to create s output variables. Let $D M U_{n}^{t}$ represent the $n$-th DMU in stage $t(t=1 \div T)$, then the input and output vectors of $D M U_{n}^{t}$ are represented as $A_{n}^{t}$ and $B_{n}^{t}$, and are shown as Equations (6) and (7) as follows [29,49].

$$
A_{n}^{t}=\left[\begin{array}{c}
a_{n}^{1 t} \\
\vdots \\
a_{n}^{m t}
\end{array}\right], A_{n}^{t} \text { denotes input vector of } D M U_{n}^{t}
$$

and

$$
B_{n}^{t}=\left[\begin{array}{c}
b_{n}^{1 t} \\
\vdots \\
b_{n}^{s t}
\end{array}\right], B_{n}^{t} \text { denotes output vector of } D M U_{n}^{t}
$$

Assume that window begins at the stage $k(1 \leq k \leq T)$ and the window length $w(1 \leq w \leq T-k)$, then the matrix of input variables $\left(A_{k w}\right)$ and the output variables $\left(B_{k w}\right)$ of each window $(k w)$ are shown in Equations (8) and (9) as follows.

$$
A_{k w}=\left[\begin{array}{cccc}
a_{1}^{k} & a_{2}^{k} & \ldots & a_{N}^{k} \\
a_{1}^{k+1} & a_{2}^{k+1} & \cdots & a_{N}^{k+1} \\
\vdots & \vdots & \ddots & \vdots \\
a_{1}^{k+w} & a_{2}^{k+w} & \cdots & a_{N}^{k+w}
\end{array}\right]
$$


and

$$
B_{k w}=\left[\begin{array}{cccc}
b_{1}^{k} & b_{2}^{k} & \cdots & b_{N}^{k} \\
b_{1}^{k+1} & b_{2}^{k+1} & \cdots & b_{N}^{k+1} \\
\vdots & \vdots & \ddots & \vdots \\
b_{1}^{k+w} & b_{2}^{k+w} & \cdots & b_{N}^{k+w}
\end{array}\right]
$$

We replace the variables of $D M U_{n}^{t}$ into Equations (8) and (9) to get the model's results. The window length $w=3$ or $w=4$, pointed to achieve the best balance of informativeness and durability of the technical efficiency [32,50]. In this paper, $w=3$ is chosen for the calculation.

\section{A Case Study}

\subsection{The Selection of DMUs}

This paper concentrates on the operational efficiency evaluation of the top commercial joint-stock banks in Vietnam. They are the 18 commercial banks that have a big influence on the Vietnam banking stock market. In a total of 18 commercial banks, there are nine from Hochiminh Stock Exchange (HOSE), and three from Hanoi Stock Exchange (HNX) [51], as presented in Table 2, below.

Table 2. List of the top commercial banks in Vietnam.

\begin{tabular}{ccccc}
\hline DMUs & Name of Banks & Code & $\begin{array}{c}\text { Net Profit after Tax } \\
\text { in 2019 (Mil. USD) }\end{array}$ & $\begin{array}{c}\text { Rank by Net Profit } \\
\text { after Tax in 2019 }\end{array}$ \\
\hline B1 & Vietinbank & CTG & 406.119 & 2 \\
B2 & BIDV & BID & 366.298 & 3 \\
B3 & Vietcombank & VCB & 793.897 & 1 \\
B4 & ACB & ACB & 257.545 & 6 \\
B5 & Sacombank & STB & 105.199 & 11 \\
B6 & SHBank & SHB & 103.614 & 12 \\
B7 & TPBank & TPB & 132.581 & 9 \\
B8 & HDBank & HDB & 172.284 & 7 \\
B9 & MilitaryBank & MBB & 345.765 & 5 \\
B10 & VPBank & VPB & 353.978 & 4 \\
B11 & NationalCitizen & NVB & 1.849 & 18 \\
B12 & OrientCommercial & OCB & 110.657 & 10 \\
B13 & VietnamMaritime & MSB & 44.720 & 13 \\
B14 & SaigonBank & SCB & 7.292 & 14 \\
B15 & VIB & VIB & 139.976 & 16 \\
B16 & BaoVietBank & BVB & 3.641 & 15 \\
B17 & SaigonCongThuong & SGB & 6.198 & 17 \\
B18 & PetrolimexGroup & PGB & 3.198 & \\
\hline
\end{tabular}

Source: Finance.vietstock.vn [51]

\subsection{Data Collection}

This research used data from 2015 to 2019. The authors considered a variety of input and output factors (i.e., essential financial indexes), which are assets (a1), deposits (a2), operating expenses (a3), liabilities (a4) as inputs; and loans (b1), net income (b2) as outputs. The data source was consolidated from the yearly financial statement report of the top commercial banks in the Vietnam stock market [51]. The unit is measured in millions of US dollars. The statistical data for each year is provided in Table 3. 
Table 3. Statistical analysis for each year.

\begin{tabular}{cccccccc}
\hline \multirow{2}{*}{ Period } & \multirow{2}{*}{ Statistics } & \multicolumn{3}{c}{ Input Factors } & \multicolumn{3}{c}{ Output Factors } \\
\cline { 2 - 7 } & & $\mathbf{a 1}$ & $\mathbf{a 2}$ & $\mathbf{a 3}$ & $\mathbf{a 4}$ & $\mathbf{b 1}$ & $\mathbf{b 2}$ \\
\hline \multirow{3}{*}{2015} & Max & $36,453.89$ & $24,194.17$ & 475.12 & $34,639.68$ & $25,322.68$ & 827.71 \\
& Min & 760.59 & 563.17 & 14.56 & 615.28 & 493.68 & 20.30 \\
& Avg & $10,168.83$ & 7065.65 & 148.94 & 9329.91 & 6187.13 & 248.47 \\
& SD & $10,904.51$ & 7215.26 & 143.55 & $10,302.97$ & 7386.57 & 259.12 \\
\hline \multirow{3}{*}{2016} & Max & $43,126.47$ & $31,112.33$ & 579.89 & $41,236.13$ & $30,581.42$ & 1002.49 \\
& Min & 816.26 & 607.18 & 16.94 & 665.64 & 532.70 & 26.34 \\
& Avg & $12,030.80$ & 8722.56 & 176.60 & $11,306.56$ & 7572.66 & 289.57 \\
& SD & $12,963.90$ & 9476.58 & 172.60 & $12,288.67$ & 8913.86 & 318.27 \\
\hline \multirow{2}{*}{2017} & Max & $51,521.67$ & $36,853.09$ & 664.41 & $49,428.97$ & $33,527.68$ & 1326.53 \\
& Min & 913.60 & 636.35 & 17.24 & 767.16 & 599.45 & 28.14 \\
& Avg & $14,550.00$ & $10,128.80$ & 215.04 & $13,698.36$ & 8805.55 & 371.36 \\
& SD & $15,672.62$ & $11,162.80$ & 202.58 & $14,954.91$ & 9859.45 & 404.71 \\
\hline & Max & $56,267.82$ & $42,410.54$ & 690.66 & $53,930.12$ & $41,839.00$ & 1497.97 \\
& Min & 873.07 & 629.02 & 19.25 & 725.88 & 581.07 & 27.08 \\
& Avg & $15,980.49$ & $11,386.86$ & 244.22 & $15,013.35$ & $10,396.45$ & 423.62 \\
& SD & $16,677.50$ & $12,595.49$ & 210.89 & $15,886.91$ & $11,896.95$ & 443.57 \\
\hline & Max & $63,849.38$ & $47,745.39$ & 739.52 & $60,521.71$ & $47,239.86$ & 1541.76 \\
& Min & 977.60 & 671.41 & 20.84 & 824.99 & 618.90 & 30.76 \\
& Avg & $17,999.59$ & $12,972.07$ & 276.86 & $16,818.52$ & $11,904.13$ & 518.52 \\
& SD & $18,522.97$ & $14,075.98$ & 235.76 & $17,494.69$ & $13,242.19$ & 527.24 \\
\hline
\end{tabular}

Source: calculated by the authors.

\section{Results Analysis}

\subsection{Pearson Correlation Coefficient Test}

Applying Equation (1), Table 4 shows the Person indicator of the factors for DMUs in $2015,2016,2017,2018$, and 2019, respectively. -1 to +1 is considered as a value range of the Pearson correlation coefficient.

Table 4. Coefficients of correlation between factors.

\begin{tabular}{|c|c|c|c|c|c|c|c|}
\hline \multirow{2}{*}{ Period } & \multirow{2}{*}{ Factors } & \multicolumn{4}{|c|}{ Input Factors } & \multicolumn{2}{|c|}{ Output Factors } \\
\hline & & a1 & a2 & a3 & a4 & b1 & b2 \\
\hline \multirow{6}{*}{2015} & Assets & 1 & & & & & \\
\hline & Deposits & 0.9860 & 1 & & & & \\
\hline & Operating Expenses & 0.9594 & 0.9541 & 1 & & & \\
\hline & Liabilities & 0.9985 & 0.9820 & 0.9527 & 1 & & \\
\hline & Loans & 0.9927 & 0.9861 & 0.9605 & 0.9909 & 1 & \\
\hline & Net Income & 0.9612 & 0.9461 & 0.9905 & 0.9564 & 0.9590 & 1 \\
\hline \multirow{6}{*}{2016} & Assets & 1 & & & & & \\
\hline & Deposits & 0.9947 & 1 & & & & \\
\hline & Operating Expenses & 0.9593 & 0.9457 & 1 & & & \\
\hline & Liabilities & 0.9998 & 0.9946 & 0.9568 & 1 & & \\
\hline & Loans & 0.9941 & 0.9856 & 0.9578 & 0.9948 & 1 & \\
\hline & Net Income & 0.9219 & 0.8931 & 0.9732 & 0.9191 & 0.9205 & 1 \\
\hline \multirow{6}{*}{2017} & Assets & 1 & & & & & \\
\hline & Deposits & 0.9948 & 1 & & & & \\
\hline & Operating Expenses & 0.9415 & 0.9272 & 1 & & & \\
\hline & Liabilities & 0.9999 & 0.9955 & 0.9372 & 1 & & \\
\hline & Loans & 0.9868 & 0.9822 & 0.9461 & 0.9860 & 1 & \\
\hline & Net Income & 0.8910 & 0.8580 & 0.9697 & 0.8863 & 0.8948 & 1 \\
\hline
\end{tabular}


Table 4. Cont.

\begin{tabular}{|c|c|c|c|c|c|c|c|}
\hline \multirow{2}{*}{ Period } & \multirow{2}{*}{ Factors } & \multicolumn{4}{|c|}{ Input Factors } & \multicolumn{2}{|c|}{ Output Factors } \\
\hline & & a1 & a2 & a3 & a4 & b1 & b2 \\
\hline \multirow{6}{*}{2018} & Assets & 1 & & & & & \\
\hline & Deposits & 0.9961 & 1 & & & & \\
\hline & Operating Expenses & 0.9199 & 0.9048 & 1 & & & \\
\hline & Liabilities & 0.9998 & 0.9969 & 0.9141 & 1 & & \\
\hline & Loans & 0.9907 & 0.9860 & 0.9105 & 0.9911 & 1 & \\
\hline & Net Income & 0.8708 & 0.8483 & 0.9628 & 0.8651 & 0.8655 & 1 \\
\hline \multirow{6}{*}{2019} & Assets & 1 & & & & & \\
\hline & Deposits & 0.9963 & 1 & & & & \\
\hline & Operating Expenses & 0.9102 & 0.8967 & 1 & & & \\
\hline & Liabilities & 0.9998 & 0.9969 & 0.9034 & 1 & & \\
\hline & Loans & 0.9914 & 0.9854 & 0.9005 & 0.9916 & 1 & \\
\hline & Net Income & 0.8773 & 0.8487 & 0.9694 & 0.8689 & 0.8714 & 1 \\
\hline
\end{tabular}

Source: calculated by the authors.

Values from 0.8483 to 1 show the positive correlation coefficients, and these input and output factors are found to be extremely correlated, proving them to be proper variables for DEA mode (i.e., Malmquist and Window model). This implies that the collected data meet the isotropic conditions and, hence, can be applied to the proposed approach of this paper.

\subsection{Productivity Growth Evaluation}

\subsubsection{Technical Efficiency Change (Catch-Up Index)}

The MPI contains the elements used to evaluate efficiency/inefficiency, which are technical change, technological change, and total factor productivity. In this section, the authors present the results of technical efficiency change. The catch-up indexes in Table 5 and Figure 2 demonstrate the technical effective changes of DMUs, indicating the progress (if indexes are greater than 1), and the regress (if indexes are less than 1) of the technical efficiency of 18 DMUs in the period of 2015 to 2019. As can be seen, most of the efficiency indexes of the 18 DMUs had a fluctuating trend, except for B5-Sacombank, B8-HDBank, and B9-MilitaryBank, which have the catch-up indexes growing continuously during that time. The majority (10 DMUs: B1, 2, 7, 8, 10, 11, 13, 14, 15, 18) achieved progressive technical changes in the total research period (2015-2019), and thus the average catch-up index was obtained at 1.0072. B10-VP Bank achieved the highest catch-up index (1.1120) but had the least-stable technical performance on average. Meanwhile, B4-ACB had the lowest average catch-up value (0.9456), and B7-TP Bank had the most stable efficiency performance.

During the 2015-2016 period, only 7 out of 18 DMUs (B1, 6, 7, 10, 13, 14, 18) achieved technical efficiency, with scores $>1$. The average technical efficiency index in this period is 1.0120. B10-VP Bank achieved the highest technical change at 1.4299, while B9-Military Bank had the lowest technical efficiency index (0.8290).

The technical efficiency of banks witnessed no improvement in 2016-2017, as the average catch-up in this period reached the lowest point of 0.9705 . Only seven of the 18 DMUs (B1, 6, 7, 11, 15, 16, 18) had catch-up indexes greater than 1, but overall, the scores dropped significantly. Among those seven, only four banks maintained technical efficiency $(B 1,6,7,18)$ from the previous period. B10-VP Bank performed the best during the previous period, but suffered a serious decline in technical efficiency, and then had the lowest efficiency performance in this period. B10's catch-up score bottomed out to 0.6582, which is also the lowest value of all indexes during the total research period (2015-2019). B15-VIB achieved the highest technical efficiency in 2016-2017, at 1.2981.

During the 2017-2018 period, the average catch-up value increased to 1.0433 when half of the DMUs (B2, 3, 4, 7, 8, 10,11, 12, 13) achieved technical efficiency. It is noticeable that many banks with low technical efficiency in the previous period had shown a significant improvement in this period (B2, 3, 4, 8, 10, 12, 13), with catch-up values greater than 1 . Meanwhile, most of the good performing banks previously $(B 1,6,15,16,18)$ failed to 
maintain their high efficiency in this period. It is worth noting that B10-VP Bank and B15-VIB swapped their positions in productivity rankings. That means, B10-VP Bank was the worst-performing bank in the previous period and then became the best effective bank in the next period (with the score at 1.4351), while B15-VIB failed to maintain the highest technical efficiency in the previous period and then had the lowest catch-up value in this period (0.9331).

Table 5. The technical efficiency change indexes.

\begin{tabular}{ccccccc}
\hline DMUs & Name of Banks & $\mathbf{2 0 1 5 - 2 0 1 6}$ & $\mathbf{2 0 1 6 - 2 0 1 7}$ & $\mathbf{2 0 1 7 - 2 0 1 8}$ & $\mathbf{2 0 1 8 - 2 0 1 9}$ & Average \\
\hline B1 & Vietinbank & 1.0000 & 1.0235 & 0.9846 & 1.0044 & 1.0032 \\
B2 & BIDV & 0.9792 & 0.8600 & 1.2214 & 0.9521 & 1.0032 \\
B3 & Vietcombank & 0.8475 & 0.9061 & 1.0586 & 1.0152 & 0.9569 \\
B4 & ACB & 0.8342 & 0.9553 & 1.0075 & 0.9856 & 0.9456 \\
B5 & Sacombank & 0.9281 & 0.9792 & 0.9974 & 1.0062 & 0.9777 \\
B6 & SHBank & 1.0105 & 1.0220 & 0.9580 & 0.9987 & 0.9973 \\
B7 & TPBank & 1.0374 & 1.0311 & 1.0599 & 1.0279 & 1.0391 \\
B8 & HDBank & 0.9646 & 0.9904 & 1.0626 & 1.2491 & 1.0667 \\
B9 & MilitaryBank & 0.8290 & 0.9438 & 0.9836 & 1.0361 & 0.9481 \\
B10 & VPBank & 1.4299 & 0.6582 & 1.4351 & 0.9253 & 1.1121 \\
B11 & NationalCitizen & 0.9075 & 1.1306 & 1.0401 & 0.9781 & 1.0141 \\
B12 & OrientCommercial & 0.9695 & 0.9320 & 1.0058 & 1.0307 & 0.9845 \\
B13 & VietnamMaritime & 1.2933 & 0.8232 & 1.1156 & 1.1234 & 1.0889 \\
B14 & SaigonBank & 1.0930 & 0.9461 & 0.9801 & 1.0029 & 1.0055 \\
B15 & VIB & 0.9843 & 1.2981 & 0.9331 & 0.9219 & 1.0344 \\
B16 & BaoVietBank & 0.9961 & 1.0435 & 0.9727 & 0.8657 & 0.9695 \\
B17 & SaigonCongThuong & 0.9949 & 0.9231 & 0.9711 & 0.9342 & 0.9558 \\
B18 & PetrolimexGroup & 1.1167 & 1.0027 & 0.9918 & 0.9986 & 1.0274 \\
\hline & Average & 1.0120 & 0.9705 & 1.0433 & 1.0031 & 1.0072 \\
& Max & 1.4299 & 1.2981 & 1.4351 & 1.2491 & 1.1121 \\
& Min & 0.8290 & 0.6582 & 0.9331 & 0.8657 & 0.9456 \\
& SD & 0.1512 & 0.1306 & 0.1187 & 0.0831 & 0.0478 \\
\hline
\end{tabular}

Source: calculated by the authors.

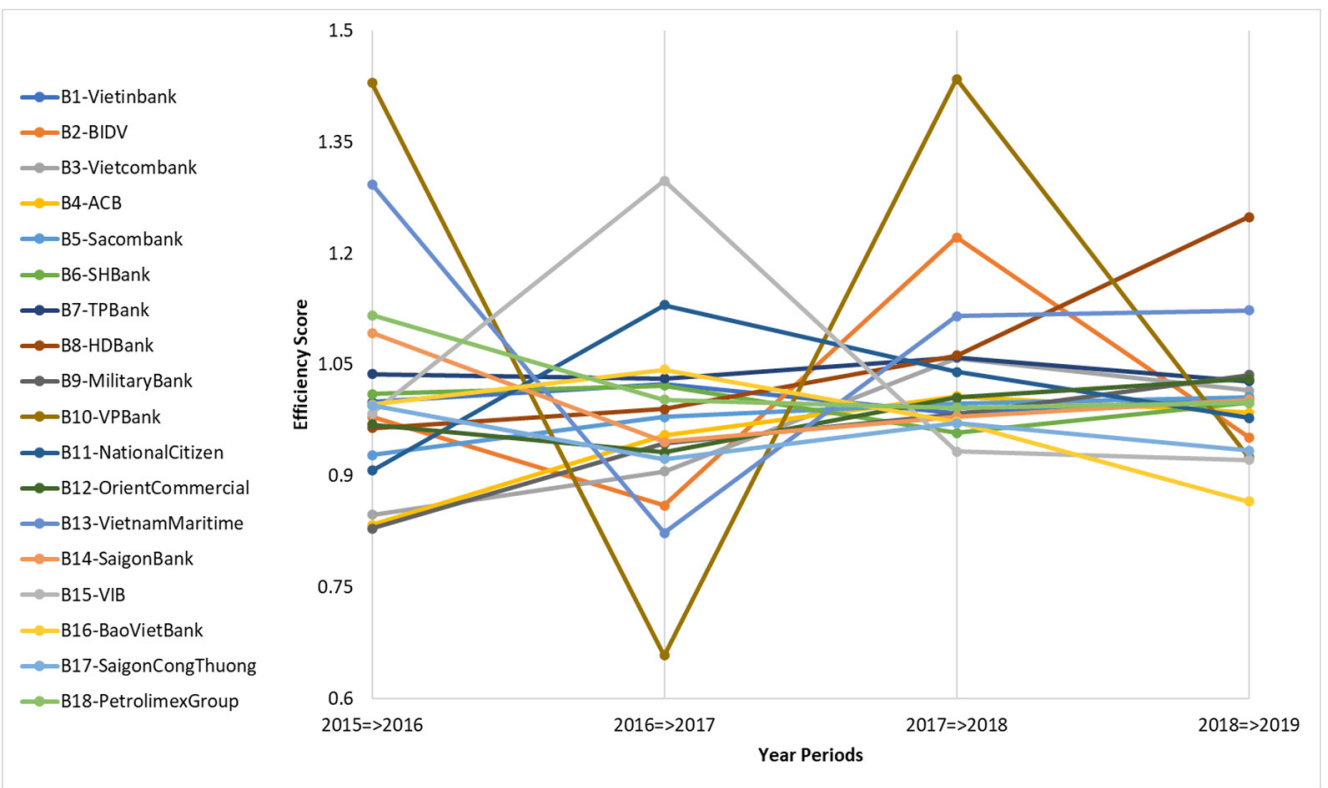

Figure 2. The efficiency change indexes of the DMUs.

Half of the banks achieved technical efficiency in the final period (2018-2019), which are B1-Vietinbank, B3-Vietcombank, B5-Sacombank, B7-TPBank, B8-HDBank, B9-MilitaryBank, B12-OrientCommercial, B13-VietnamMaritime, and B14-SaigonBank. However, the indexes 
dropped significantly, thus, the average catch-up decreased to 1.0031 in this period. The efficiency of B8-HDBank had been continuously improved over the years and resulted in being the best performing bank during 2018-2019, with a catch-up index of 1.2491. B16-BaoVietBank was the worst-performing bank in this period, with a technical efficiency index of 0.8657 .

\subsubsection{Technological Change (Frontier-Shift Index)}

The frontier-shift indexes of the DMUs are shown in Table 6, which are to measure their changes in technology between two periods. As can be seen, most of the banks maintained a high technological efficiency with indexes greater than 1 in all stages. On average, except for B14-SaigonBank, the remaining ones all of the banks (17 out of 18) obtained high efficiencies with frontier-shift indexes more than 1 . Therefore, within the total research period (2015-2019), the medium point of the technological efficiency of DMUs resulted in a progressive score, at 1.0265. B10-VP Bank obtained the highest average technological score (1.0706), while B14-SaigonBank was the only bank to have the average frontier-shift index lower than 1 (at 0.9863). It can be observed in Figure 3 that B10 had the least-stable technological performance, while the rest had slight fluctuations during 2015-2019.

Table 6. The technological change indexes.

\begin{tabular}{|c|c|c|c|c|c|c|}
\hline DMUs & Name of Banks & 2015-2016 & 2016-2017 & 2017-2018 & 2018-2019 & Average \\
\hline B1 & Vietinbank & 1.0001 & 1.0175 & 1.0287 & 1.0054 & 1.0129 \\
\hline B2 & BIDV & 1.0064 & 1.0941 & 1.0150 & 1.0290 & 1.0361 \\
\hline B3 & Vietcombank & 1.0821 & 1.0407 & 1.0299 & 1.0114 & 1.0410 \\
\hline B4 & $\mathrm{ACB}$ & 1.0674 & 1.0378 & 1.0258 & 1.0127 & 1.0359 \\
\hline B5 & Sacombank & 1.0007 & 1.0321 & 1.0296 & 1.0094 & 1.0179 \\
\hline B6 & SHBank & 1.0092 & 1.0208 & 1.0123 & 1.0391 & 1.0204 \\
\hline B7 & TPBank & 1.0484 & 1.0516 & 1.0093 & 1.0118 & 1.0303 \\
\hline B8 & HDBank & 1.0724 & 1.0565 & 1.0041 & 0.9709 & 1.0260 \\
\hline B9 & MilitaryBank & 1.0751 & 1.0596 & 1.0036 & 1.0094 & 1.0369 \\
\hline B10 & VPBank & 1.0336 & 1.3578 & 0.8370 & 1.0540 & 1.0706 \\
\hline B11 & NationalCitizen & 1.0110 & 1.0319 & 1.0335 & 1.0106 & 1.0218 \\
\hline B12 & OrientCommercial & 1.0384 & 1.0463 & 1.0080 & 1.0117 & 1.0261 \\
\hline B13 & VietnamMaritime & 1.0847 & 1.0526 & 1.0101 & 1.0123 & 1.0400 \\
\hline B14 & SaigonBank & 1.0034 & 0.9800 & 0.9606 & 1.0012 & 0.9863 \\
\hline B15 & VIB & 1.0390 & 1.0276 & 1.0029 & 1.0086 & 1.0195 \\
\hline B16 & BaoVietBank & 1.0139 & 1.0424 & 1.0209 & 1.0090 & 1.0215 \\
\hline B17 & SaigonCongThuong & 0.9861 & 1.0714 & 1.0250 & 1.0160 & 1.0246 \\
\hline \multirow[t]{5}{*}{ B18 } & PetrolimexGroup & 1.0113 & 1.0112 & 1.0074 & 1.0078 & 1.0094 \\
\hline & Average & 1.0324 & 1.0573 & 1.0035 & 1.0128 & 1.0265 \\
\hline & $\operatorname{Max}$ & 1.0847 & 1.3578 & 1.0335 & 1.0540 & 1.0706 \\
\hline & Min & 0.9861 & 0.9800 & 0.8370 & 0.9709 & 0.9863 \\
\hline & SD & 0.0323 & 0.0790 & 0.0448 & 0.0166 & 0.0171 \\
\hline
\end{tabular}

Source: calculated by the authors.

It can be concluded that the technology development and innovation of the banking industry in Vietnam has been performed effectively in recent years. The average technological efficiency index in each research period was above 1, at 1.0323 during 2015-2016, 1.0573 during 2016-2017, 1.0035 during 2017-2018, and 1.0128 during 2018-2019. Only one or two banks did not achieve technological progress in each period, namely B17SaigonCongThuong from 2015 to 2016, B14-SaigonBank in the period of 2016-2017, B10VPBank and B14-SaigonBank in the period of 2017-2018, and B8-HDBank in the period of 2018-2019. The bank that obtained the highest frontier-shift index in each period was B13VietnamMaritime (during 2015-2016, at 1.0847), B10-VPBank (during 2016-2017, at 1.3578 and during 2018-2019, at 1.0540), and B11-NationalCitizen (during 2017-2018, at 1.0335). 


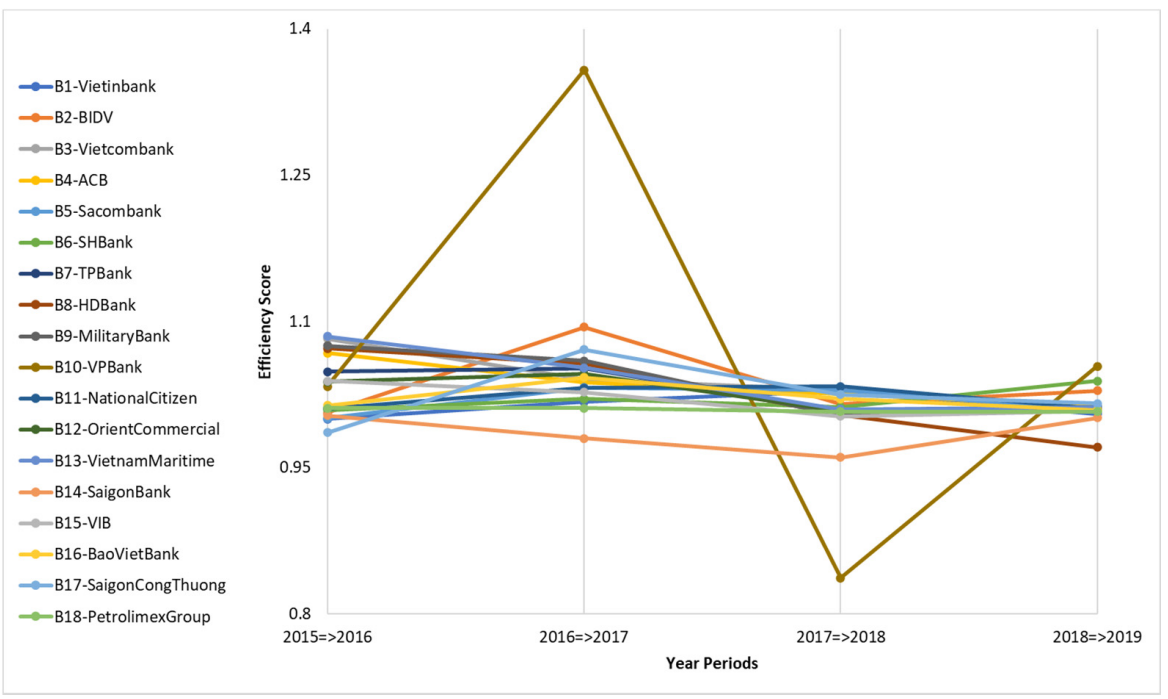

Figure 3. The technological change indexes of the DMUs.

\subsubsection{Malmquist Productivity Indicator (MPI)}

MPI is a highly useful component to evaluate the performance in many areas, such as the automobile industry, finance, education, medical, and insurance, to name a few. From the results in Table 7 and Figure 4, the average Malmquist index of DMUs $=1.0306(>1)$, which reflects that the majority (11 DMUs: B1, 2, 6, 7, 8, 10, 11, 12, 13, 15, and 18) achieved progress in total factor productivity. The total performance of most DMUs fluctuated during the research period (2015-2019), except for B7-TPBank, which had a decreasing efficiency, and B8-HDBank, which had a continuous improvement in productivity. On average, B10-VP Bank achieved the highest MPI value (1.1370) but had the least-stable performance. The lowest average MPI value of 0.9784 belongs to $\mathrm{B} 4-\mathrm{ACB}$, meaning that it was the least-efficient bank during 2015-2019. B1-Vietinbank, B7-TPBank, and B8-HDBank had the most stable performance (MPI values were greater than 1 in all stages).

Table 7. Malmquist productivity indexes (2015-2019).

\begin{tabular}{ccccccc}
\hline DMUs & Name of Banks & $\mathbf{2 0 1 5 - 2 0 1 6}$ & $\mathbf{2 0 1 6 - 2 0 1 7}$ & $\mathbf{2 0 1 7 - 2 0 1 8}$ & $\mathbf{2 0 1 8 - 2 0 1 9}$ & Average \\
\hline B1 & Vietinbank & 1.0001 & 1.0415 & 1.0129 & 1.0099 & 1.0161 \\
B2 & BIDV & 0.9855 & 0.9409 & 1.2397 & 0.9797 & 1.0365 \\
B3 & Vietcombank & 0.9171 & 0.9429 & 1.0903 & 1.0268 & 0.9943 \\
B4 & ACB & 0.8904 & 0.9914 & 1.0335 & 0.9981 & 0.9784 \\
B5 & Sacombank & 0.9287 & 1.0107 & 1.0269 & 1.0156 & 0.9955 \\
B6 & SHBank & 1.0198 & 1.0433 & 0.9698 & 1.0378 & 1.0177 \\
B7 & TPBank & 1.0876 & 1.0843 & 1.0698 & 1.0401 & 1.0705 \\
B8 & HDBank & 1.0345 & 1.0463 & 1.0670 & 1.2127 & 1.0901 \\
B9 & MilitaryBank & 0.8913 & 1.0000 & 0.9871 & 1.0458 & 0.9810 \\
B10 & VPBank & 1.4779 & 0.8937 & 1.2012 & 0.9752 & 1.1370 \\
B11 & NationalCitizen & 0.9175 & 1.1666 & 1.0749 & 0.9885 & 1.0369 \\
B12 & OrientCommercial & 1.0067 & 0.9751 & 1.0138 & 1.0428 & 1.0096 \\
B13 & VietnamMaritime & 1.4028 & 0.8666 & 1.1269 & 1.1373 & 1.1334 \\
B14 & SaigonBank & 1.0968 & 0.9273 & 0.9415 & 1.0041 & 0.9924 \\
B15 & VIB & 1.0226 & 1.3340 & 0.9358 & 0.9298 & 1.0556 \\
B16 & BaoVietBank & 1.0099 & 1.0877 & 0.9931 & 0.8735 & 0.9910 \\
B17 & SaigonCongThuong & 0.9810 & 0.9890 & 0.9954 & 0.9491 & 0.9786 \\
B18 & PetrolimexGroup & 1.1293 & 1.0139 & 0.9992 & 1.0064 & 1.0372 \\
\hline & Average & 1.0444 & 1.0197 & 1.0433 & 1.0152 & 1.0306 \\
& Max & 1.4779 & 1.3340 & 1.2397 & 1.2127 & 1.1370 \\
& Min & 0.8904 & 0.8666 & 0.9358 & 0.8735 & 0.9784 \\
& SD & 0.1598 & 0.1071 & 0.0820 & 0.0738 & 0.0497 \\
\hline
\end{tabular}




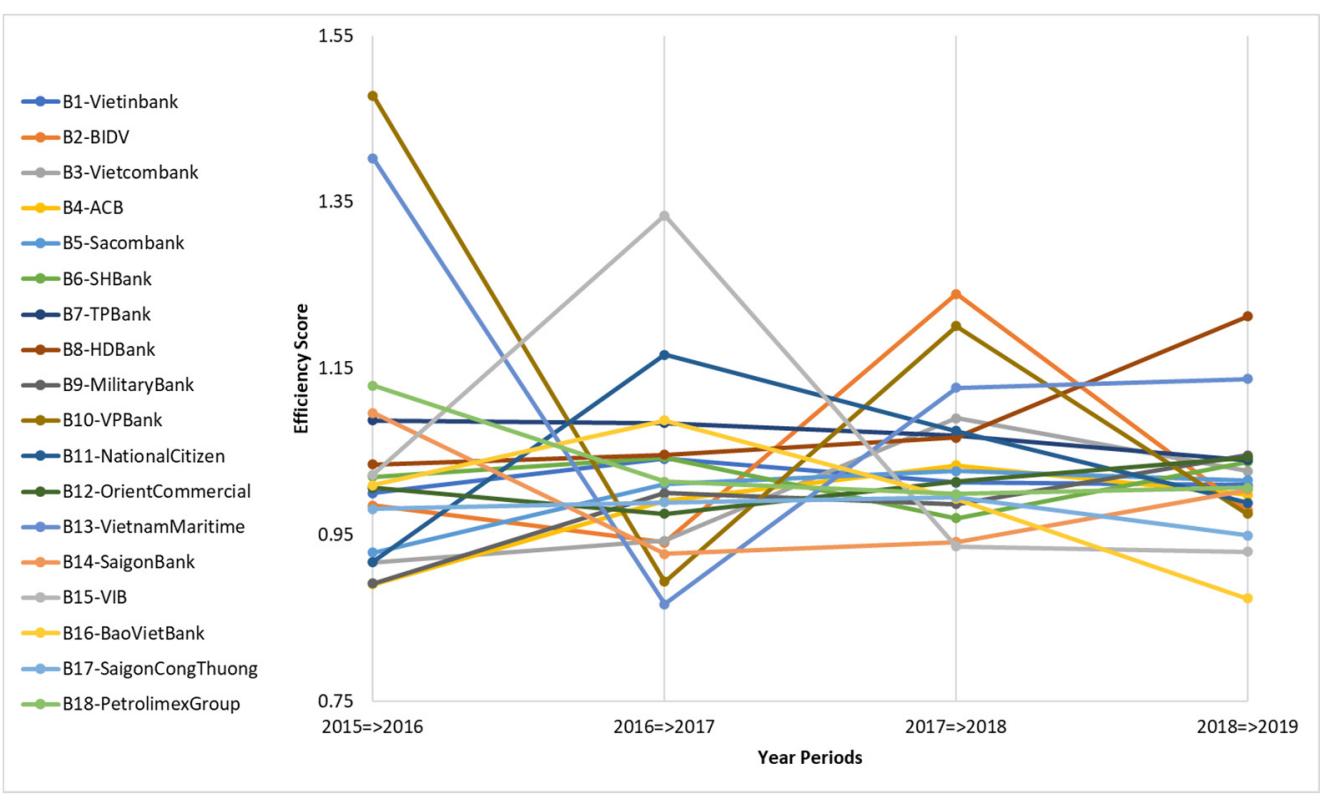

Figure 4. Malmquist productivity indexes of the DMUs (2015-2019).

Overall, in every stage, the number of effective banks is in the majority, namely, 11 DMUs (B1, 6, 7, 8, 10, 12, 13, 14, 15, 16, 18) during 2015-2016, 10 DMUs (B1, 5, 6, 7, $8,9,11,15,16,18)$ during 2016-2017, 11 DMUs (B1, 2, 3, 4, 5, 7, 8, 10, 11, 12, 13) during 2017-2018, 11 DMUs (B1, 3, 5, 6, 7, 8, 9, 12, 13, 14, 18) during 2018-2019. The average MPI value of DMUs was above 1 in all stages, at 1.0444 during 2015-2016, 1.0197 during 2016-2017, 1.0433 during 2017-2018, and 1.0152 during 2018-2019. The highest position in the total factor productivity among banks changed over periods, which are B10-VPBank during 2015-2016, B15-VIB during 2016-2017, B2-BIDV during 2017-2018, and B8-HDBank during 2018-2019, with scores of 1.4779, 1.3340, 1.2397, and 1.2127, respectively. In contrast, B4-ACB, B13-VietnamMaritime, B15-VIB, and B16-BaoVietBank were the worst-performing banks in each stage, with MPI values of $0.8904,0.8666,0.9358$, and 0.8735 , respectively.

\subsection{DEA Window Analysis}

At this part, the performance of DMUs (i.e., 18 commercial banks in Vietnam) for the period from 2015 to 2019 is ranked by the DEA Window model. To help, authors found a whole view of DMUs' performance ranking, the Window results of the whole period were analyzed. Then, three windows of the 3 years, showing the most effective balance of informativeness and durability of the efficiency scores, were used for ranking the performance of these DMUs (i.e., 1st Window: 2015-2017, 2nd Window: 2016-2018, 3rd Window: 2017-2019) [50].

\subsubsection{DEA Window of the Whole Period}

The efficiency scores of 18 DMUs obtained for the whole period (2015-2019) are shown in Table 8. B1-Vietinbank is shown ranking at No. 1, with the highest efficiency score of 0.9789 , while B13-VietnamMaritime had the worst efficiency score of 0.5583 .

It can be concluded from Figure 5 that most of the indexes had a mild fluctuating trend, except for B1-Vietinbank, B7-TPBank, B8-HDBank, and B9-MilitaryBank, which had their indexes increased steadily or remained stable during the time of 2015-2019. 
Table 8. The Window results of the whole period (2015-2019).

\begin{tabular}{ccccccccc}
\hline DMUs & Name of Banks & $\mathbf{2 0 1 5}$ & $\mathbf{2 0 1 6}$ & $\mathbf{2 0 1 7}$ & $\mathbf{2 0 1 8}$ & $\mathbf{2 0 1 9}$ & Average & Rank \\
\hline B1 & Vietinbank & 0.9515 & 0.9543 & 0.9889 & 1 & 1 & 0.9789 & 1 \\
B2 & BIDV & 0.9979 & 0.9539 & 0.8548 & 1 & 1 & 0.9613 & 4 \\
B3 & Vietcombank & 0.9384 & 0.8103 & 0.8041 & 0.8700 & 0.8966 & 0.8639 & 10 \\
B4 & ACB & 1 & 0.9381 & 0.9388 & 0.9424 & 0.9449 & 0.9528 & 6 \\
B5 & Sacombank & 0.8463 & 0.7959 & 0.8039 & 0.8385 & 0.8661 & 0.8301 & 12 \\
B6 & SHBank & 0.9190 & 0.9605 & 1 & 0.9712 & 1 & 0.9701 & 3 \\
B7 & TPBank & 0.7113 & 0.7760 & 0.8065 & 0.8569 & 0.8810 & 0.8063 & 15 \\
B8 & HDBank & 0.7255 & 0.7476 & 0.7645 & 0.8294 & 0.9681 & 0.8070 & 14 \\
B9 & MilitaryBank & 0.8153 & 0.8291 & 0.8151 & 0.8185 & 0.8459 & 0.8248 & 13 \\
B10 & VPBank & 0.8529 & 0.9359 & 1 & 1 & 1 & 0.9578 & 5 \\
B11 & NationalCitizen & 0.5694 & 0.5678 & 0.6560 & 0.7058 & 0.6624 & 0.6323 & 17 \\
B12 & OrientCommercial & 0.8440 & 0.8258 & 0.8172 & 0.8225 & 0.8853 & 0.8390 & 11 \\
B13 & VietnamMaritime & 0.3969 & 0.5551 & 0.5394 & 0.6145 & 0.6856 & 0.5583 & 18 \\
B14 & SaigonBank & 0.9201 & 1 & 0.9537 & 0.9223 & 0.9137 & 0.9420 & 7 \\
B15 & VIB & 0.7951 & 0.8641 & 1 & 0.9960 & 0.9584 & 0.9227 & 9 \\
B16 & BaoVietBank & 0.7901 & 0.6968 & 0.8421 & 0.8867 & 0.7752 & 0.7982 & 16 \\
B17 & SaigonCongThuong & 0.9374 & 0.9367 & 0.9490 & 0.9542 & 0.9138 & 0.9382 & 8 \\
B18 & PetrolimexGroup & 0.9092 & 0.9803 & 0.9851 & 0.9948 & 1 & 0.9739 & 2 \\
\hline
\end{tabular}

Source: calculated by the authors.

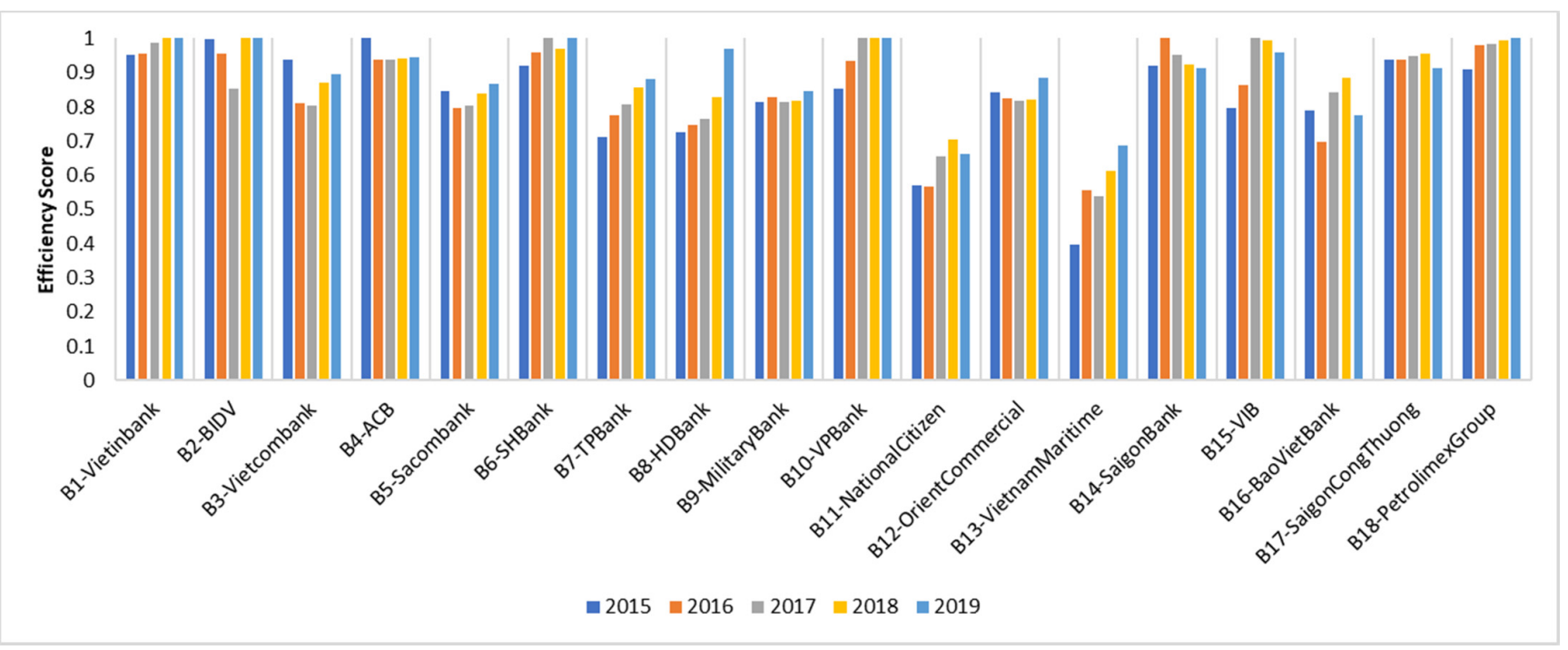

Figure 5. Variation over a year of the DMUs (Window of 5 years).

\subsubsection{DEA Window of 3-Year Period}

The scores of 18 DMUs obtained from the Window model for a 3-year period is shown in Table 9, and their rankings are illustrated in Figure 6. It is found that there is a slight change in the rankings of the DMUs in this table compared to Table 8. As shown in Table 9, B6-SHBank ranked first instead of B1-Vietinbank in Table 8, with an average score of 0.9876 . B13-VietnamMaritime again had the worst average score, at 0.5621 in Table 9. This table also gives each DMU a higher resolution on the efficiency scores.

DMUs are separated into three groups based on the average efficiency rankings of them shown in Figure 6. The first group and the third group include the top and the worst three banks. The remaining banks belong to the 2nd group.

The 1st group includes B6-SHBank, B1-Vietinbank, and B18-PetrolimexGroup. The efficiency scores of B6-SHBank increased steadily from 2015 to 2017, from 0.9687 in 2015 to 0.9883 in 2016, and then reached 1 in 2017. The efficiency score dropped to 0.9813 in 2018 and then increased back to 1 in 2019. B1-Vietinbank had a score of 0.9706 in 2015, bottomed out to 0.9655 in 2016, increased to 0.9932 in 2017, and kept growing to 1 in 2018, and 2019. 
B18-PetrolimexGroup's efficiency has increased annually as the scores improved as follows: 0.9274 (2015)-0.9953 (2016)-0.9979 (2017)-0.9996 (2018)-1 (2019).

Table 9. The Window results for a 3-year period.

\begin{tabular}{|c|c|c|c|c|c|c|c|c|}
\hline DMUs & Name of Banks & 2015 & 2016 & 2017 & 2018 & 2019 & Average & Rank \\
\hline \multirow{4}{*}{ B1 } & \multirow{3}{*}{ Vietinbank } & 0.9706 & 0.9730 & 1 & & & & \\
\hline & & & 0.9579 & 0.9906 & 1 & & & \\
\hline & & & & 0.9889 & 1 & 1 & & \\
\hline & Average & 0.9706 & 0.9655 & 0.9932 & 1 & 1 & 0.9859 & 2 \\
\hline \multirow{4}{*}{ B2 } & \multirow{3}{*}{ BIDV } & 1 & 0.9963 & 0.8996 & & & & \\
\hline & & & 0.9652 & 0.8560 & 1 & & & \\
\hline & & & & 0.8548 & 1 & 1 & & \\
\hline & Average & 1 & 0.9807 & 0.8701 & 1 & 1 & 0.9702 & 4 \\
\hline \multirow{4}{*}{ B3 } & \multirow{3}{*}{ Vietcombank } & 0.9401 & 0.8571 & 0.8266 & & & & \\
\hline & & & 0.8115 & 0.8053 & 0.8711 & & & \\
\hline & & & & 0.8041 & 0.8700 & 0.8966 & & \\
\hline & Average & 0.9401 & 0.8343 & 0.8120 & 0.8706 & 0.8966 & 0.8707 & 10 \\
\hline \multirow{4}{*}{$\mathrm{B} 4$} & & 1 & 0.9643 & 0.9651 & & & & \\
\hline & $\mathrm{ACB}$ & & 0.9404 & 0.9404 & 0.9450 & & & \\
\hline & & & & 0.9388 & 0.9424 & 0.9449 & & \\
\hline & Average & 1 & 0.9524 & 0.9481 & 0.9437 & 0.9449 & 0.9578 & 7 \\
\hline \multirow{4}{*}{ B5 } & \multirow{3}{*}{ Sacombank } & 0.8694 & 0.8179 & 0.8262 & & & & \\
\hline & & & 0.8002 & 0.8076 & 0.8419 & & & \\
\hline & & & & 0.8039 & 0.8385 & 0.8661 & & \\
\hline & Average & 0.8694 & 0.8090 & 0.8125 & 0.8402 & 0.8661 & 0.8395 & 12 \\
\hline \multirow{4}{*}{ B6 } & \multirow{3}{*}{ SHBank } & 0.9687 & 0.9971 & 1 & & & & \\
\hline & & & 0.9795 & 1 & 0.9843 & & & \\
\hline & & & & 1 & 0.9782 & 1 & & \\
\hline & Average & 0.9687 & 0.9883 & 1 & 0.9813 & 1 & 0.9876 & 1 \\
\hline \multirow{4}{*}{ B7 } & & 0.7277 & 0.7771 & 0.8072 & & & & \\
\hline & TPBank & & 0.7760 & 0.8065 & 0.8571 & & & \\
\hline & & & & 0.8065 & 0.8569 & 0.8810 & & \\
\hline & Average & 0.7277 & 0.7765 & 0.8067 & 0.8570 & 0.8810 & 0.8098 & 15 \\
\hline \multirow{4}{*}{ B8 } & & 0.7486 & 0.7723 & 0.7880 & & & & \\
\hline & HDBank & & 0.7490 & 0.7699 & 0.8300 & & & \\
\hline & & & & 0.7645 & 0.8294 & 0.9681 & & \\
\hline & Average & 0.7486 & 0.7606 & 0.7741 & 0.8297 & 0.9681 & 0.8162 & 14 \\
\hline \multirow{4}{*}{ B9 } & & 0.8424 & 0.8592 & 0.8458 & & & & \\
\hline & MilitaryBank & & 0.8426 & 0.8312 & 0.8224 & & & \\
\hline & & & & 0.8174 & 0.8185 & 0.8459 & & \\
\hline & Average & 0.8424 & 0.8509 & 0.8315 & 0.8205 & 0.8459 & 0.8382 & 13 \\
\hline \multirow{4}{*}{ B10 } & & 0.8870 & 0.9622 & 1 & & & & \\
\hline & VPBank & & 0.9417 & 1 & 1 & & & \\
\hline & & & & 1 & 1 & 1 & & \\
\hline & Average & 0.8870 & 0.9519 & 1 & 1 & 1 & 0.9678 & 5 \\
\hline \multirow{4}{*}{ B11 } & & 0.6023 & 0.5694 & 0.6572 & & & & \\
\hline & NationalCitizen & & 0.5678 & 0.6560 & 0.7058 & & & \\
\hline & & & & 0.6560 & 0.7058 & 0.6646 & & \\
\hline & Average & 0.6023 & 0.5686 & 0.6564 & 0.7058 & 0.6646 & 0.6395 & 17 \\
\hline \multirow{4}{*}{ B12 } & & 0.8472 & 0.8463 & 0.8241 & & & & \\
\hline & OrientCommercial & & 0.8340 & 0.8181 & 0.8236 & & & \\
\hline & & & & 0.8172 & 0.8225 & 0.8853 & & \\
\hline & Average & 0.8472 & 0.8402 & 0.8198 & 0.8231 & 0.8853 & 0.8431 & 11 \\
\hline
\end{tabular}


Table 9. Cont.

\begin{tabular}{|c|c|c|c|c|c|c|c|c|}
\hline DMUs & Name of Banks & 2015 & 2016 & 2017 & 2018 & 2019 & Average & Rank \\
\hline \multirow{4}{*}{ B13 } & & 0.4056 & 0.5692 & 0.5394 & & & & \\
\hline & VietnamMaritime & & 0.5614 & 0.5394 & 0.6145 & & & \\
\hline & & & & 0.5394 & 0.6145 & 0.6856 & & \\
\hline & Average & 0.4056 & 0.5653 & 0.5394 & 0.6145 & 0.6856 & 0.5621 & 18 \\
\hline \multirow{4}{*}{ B14 } & & 0.9349 & 1 & 0.9537 & & & & \\
\hline & SaigonBank & & 1 & 0.9537 & 0.9223 & & & \\
\hline & & & & 1 & 0.9554 & 0.9621 & & \\
\hline & Average & 0.9349 & 1 & 0.9691 & 0.9388 & 0.9621 & 0.9610 & 6 \\
\hline \multirow{4}{*}{ B15 } & & 0.8135 & 0.8666 & 1 & & & & \\
\hline & VIB & & 0.8644 & 1 & 0.9969 & & & \\
\hline & & & & 1 & 0.9960 & 0.9584 & & \\
\hline & Average & 0.8135 & 0.8655 & 1 & 0.9964 & 0.9584 & 0.9268 & 9 \\
\hline \multirow{4}{*}{ B16 } & & 0.7914 & 0.7110 & 0.8461 & & & & \\
\hline & BaoVietBank & & 0.7057 & 0.8437 & 0.8867 & & & \\
\hline & & & & 0.8421 & 0.8867 & 0.7752 & & \\
\hline & Average & 0.7914 & 0.7084 & 0.8440 & 0.8867 & 0.7752 & 0.8011 & 16 \\
\hline \multirow{4}{*}{ B17 } & & 0.9491 & 0.9493 & 0.9669 & & & & \\
\hline & SaigonCongThuong & & 0.9767 & 0.9576 & 0.9742 & & & \\
\hline & & & & 0.9542 & 0.9659 & 0.9191 & & \\
\hline & Average & 0.9491 & 0.9630 & 0.9596 & 0.9701 & 0.9191 & 0.9522 & 8 \\
\hline \multirow{4}{*}{ B18 } & & 0.9274 & 0.9999 & 1 & & & & \\
\hline & PetrolimexGroup & & 0.9908 & 1 & 1 & & & \\
\hline & & & & 0.9937 & 0.9992 & 1 & & \\
\hline & Average & 0.9274 & 0.9953 & 0.9979 & 0.9996 & 1 & 0.9841 & 3 \\
\hline
\end{tabular}

Source: calculated by the authors.

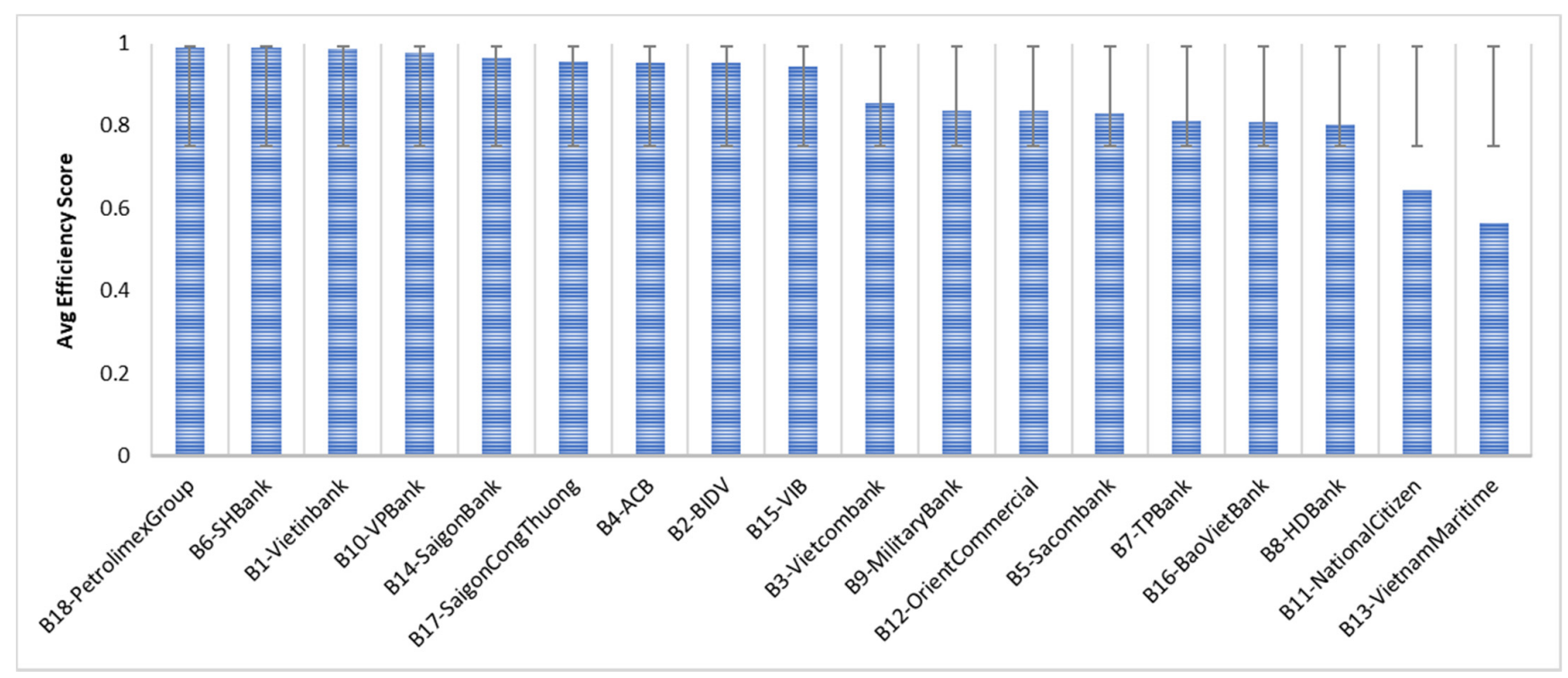

Figure 6. Average efficiency ranking of DMUs (2015-2019).

The 2nd group consists of B2-BIDV, B10-VPBank, B14-SaigonBank, B4-ACB, B17SaigonCongThuong, B15-VIB, B3-Vietcombank, B12-OrientCommercial, B5-Sacombank, B9-MilitaryBank, B8-HDBank, and B7-TPBank. While most of them had the efficiency performance that fluctuated year over year, B10-VPBank had a steady increasing performance, improved significantly from 0.8870 in 2015 to 0.9519 in 2016, then to 1 in 2017 and remained stable in 2018 and 2019. B10-VPBank is one of the joint stock commercial banks with a long history in Vietnam. This result is reasonable as the bank was reported 
to achieve a sustainable and impressive operation compared to the general context of the whole market [52].

The 3rd group includes B16-BaoVietBank, B11-NationalCitizen, and B13-VietnamMaritime. These banks could not reach a score of 1.00 in any research period. Furthermore, all the efficiency scores that they achieved were below 0.9.

\section{Discussions and Conclusions}

The Vietnamese commercial banking system performs a crucial role in providing credit to enterprises. Therefore, the stability of the banking sector is pivotal to the Vietnamese economy. This study takes advantage of both DEA efficiency-based models, including Malmquist index measurements and Window analysis, to assess the banks' performance in Vietnam, especially considering the period prior to the COVID-19 crisis. In detail, the assessment involves the performance of 18 Vietnamese commercial banks in 2015-2019 while taking four inputs (assets, deposits, operating expenses, liabilities) and two outputs (loans, net income) into account. By deriving the Malmquist indexes, the productivity growth rates of the banks over time were obtained. Moreover, decomposition of the indexes enables us to discern the cause of efficiency improvement into technical change and/or frontier shift driven by group-wide pertinent trends. The Window model of the Whole Period and the model of 3 years generate and rank the banks' efficiency in every single year in 2015-2019 by benchmarking them against the efficiency frontier.

In terms of technical efficiency, B3-Vietcombank, B5-Sacombank, B8-HDBank, B9MilitaryBank, and B12-OrientCommercial achieved a noticeable improvement, from a regressive score in 2015 to a progressive score in 2019. From Table 5, their catch-up scores increased from $0.8475,0.9281,0.9646,0.8290$, and 0.9695 to $1.0152,1.0062,1.2491,1.0361$, and 1.0307, respectively. However, the average technical efficiency slightly decreased, from 1.0120 in 2015 to 1.0031 in 2019 . That is because most banks had a decline in their scores during this period, especially B10-VPBank, which experienced a dramatic fall in its efficiency, even though this bank achieved the highest catch-up index during 2015-2016 and 2017-2018.

Regarding technological progress, it is noteworthy that a large proportion of banks achieved scores greater than 1 in all stages. Nevertheless, their technological efficiencies tended to decrease, then the average frontier-shift index for the period 2015-2019 suffered a slight decline, from 1.0324 to 1.0128 (see Table 6). Only 6 out of 18 banks improved their technological capabilities, namely B1-Vietinbank, B2-BIDV, B5-Sacombank, B6-SHBank, B10-VPBank, and B17-SaigonCongThuong, from 1.0001, 1.0064, 1.0007, 1.0092, 1.0336, 0.9861 in 2015 to $1.0054,1.0290,1.0094,1.0391,1.0540$, and 1.0160 in 2019, respectively.

As seen in Table 7, a large majority of banks (about $60 \%$ ) were able to achieve MPIs higher than 1 in each period. That means most banks balanced their effort into both technical and technological performance to obtain an overall progressive outcome. It can also be found that 11 out of 18 banks achieved progressive average MPI values for the total research period while the rest need to balance their technical and technological performance better. The average MPI values of all banks for the whole period dropped from 1.0444 in 2015 to 1.0152 in 2019. Figure 7 demonstrates the correlation relationship among MPI, technical efficiency, and technological efficiency. Note that all averages of technological indexes are higher than 1 , indicating that the technical efficiency indexes are the determinants for productivity growth. No doubt that the MPI trend is caused by the technical efficiency trend, as can be observed in Figure 7.

The DEA Window analysis indicated that the DMUs had different efficiency performances during 2015-2019. B6-SHBank, B1-Vietinbank, and B18-PetrolimexGroup are in the 1st group with the best performances. The 2nd group includes B2-BIDV, B10VPBank, B14-SaigonBank, B4-ACB, B17-SaigonCongThuong, B15-VIB, B3-Vietcombank, B12-OrientCommercial, B5-Sacombank, B9-MilitaryBank, B8-HDBank, and B7-TPBank, followed by the 3rd group that includes B16-BaoVietBank, B11-NationalCitizen, and B13VietnamMaritime. It is noteworthy that B13-VietnamMaritime had the lowest average 
efficiency ranking of DMUs (Figure 6) but one of the best indicators of average productivity change (Figure 7). It can be expounded that having a progressive productivity growth rate in no way means that the bank is an efficient performer. Although its indicators related to growth performance increased remarkably over time compared to others, the bank somewhat failed to transform its input resources into outputs in the most efficient way compared to other banks.

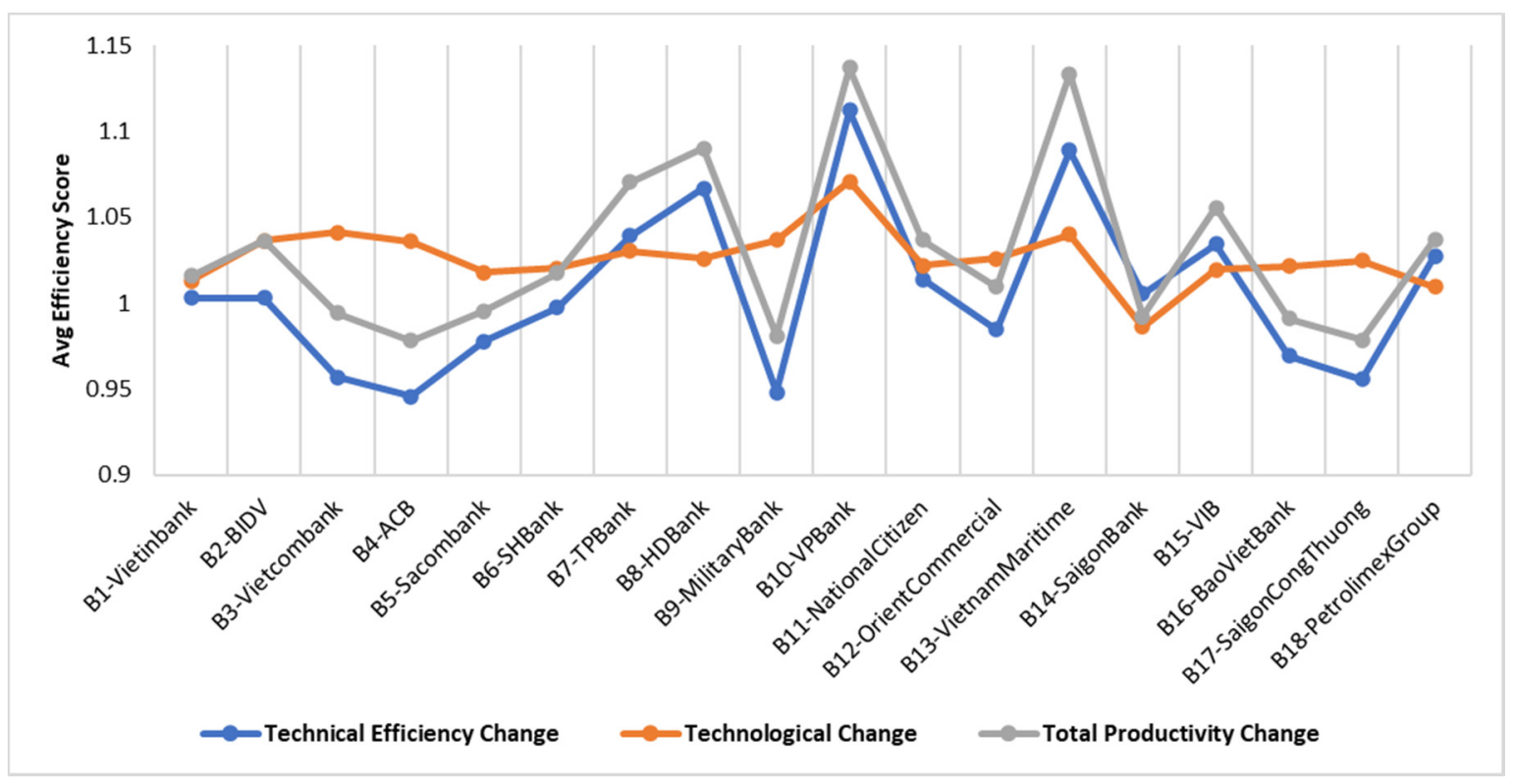

Figure 7. Average productivity change and its components (2015-2019).

The findings from the analysis of two models show that, while some banks do not rank well in various existing bank rankings [53] or have modest productivity growth indexes, they do achieve perfect efficiency and rank highly based on the Window analysis. The divergence from the existing rankings is attributable to the mechanism of the DEA approach, which ranks the banks based on their relative efficiency rather than absolute performance. For example, B6-SHBank, B1-Vietinbank, and B18-PetrolimexGroup achieve one of the worst indicators in the average productivity change (see Figure 7) but are the most efficient banks on average (see Figure 6). The result in no way means they are currently Vietnam's leading financial institutions or that they achieve the best performance in any specific aspect. Rather, it implies that these three banks were able to generate the best possible outcomes in loans and net income given their current input resources. In contrast, and somehow contrary to the common impression, B10-VPBank, B8-HDBank, and B13-VietnamMaritime have the worst average efficiency despite having the best average productivity growth over time, indicating that they have not been translating their resources to their full potential in terms of loans and net income. As a result, there is a lot of opportunities for them to increase efficiency. Rather than expanding resources, they can improve their efficiency by making better use of what they already have. According to the correlation relationship of the performance indexes as in Figure 7, for most of the banks, the effects of technical change and the frontier shift are significantly different in strength, for which the total productivity change is caused by an exceptionally strong effect in technical efficiency. The reason behind the change can be traced to policies and/or economic situations.

To conclude, the main contributions of this research can be summarized as follows. Methodologically, by using DEA approaches (Malmquist and Window models), the current study provides a viable and complete efficiency assessment process of the banking sector, discerning two pictures on bank performance, which are productivity improvement and efficiency performance. From the literature review, there has not been carried out a thorough investigation examining the Vietnamese banks as outlined in this research using 
the proposed framework, which can constitute the novelty of the study and is a research gap that needs to be bridged. Regarding practical implications, the results from both models offer comprehensive insights into the efficiency of the top 18 commercial banks. In Vietnam, changing customer expectations and improved technological capabilities have been a daunting problem for banks. In the context of the rising competition from a handful of start-ups that use technology to create unique customer experiences around banking and other financial services, most banks are forced to respond by innovating themselves. Most notably, the effects of the global pandemic are changing how banks adapt to digital technology. Vietnamese banks, like banks all over the world, will be faced with a difficult choice when deciding to invest in their technology systems to meet the change in the current trend of shopping and consuming services [54]. Towards this end, this research can be a significant material for banking decision-makers to look at their current status in terms of crucial drivers in the industry.

Some limitations to this paper can be outlined as follows. First, input and output variable selection are not fully reflected all over the financial indicators of the banking industry; thus, future studies should consider more dimensions such as total capital, equity, securities, number of employees, or non-financial aspects, in order to give a higher resolution on the efficiency scores. Second, future studies should include quantitative approaches, such as combining the DEA models with a qualitative method, which uses fuzzy multiple criteria decision making to provide more robust results. As previously discussed, the global COVID-19 pandemic with an outbreak period from the end of 2019 to 2021 has been causing unprecedented disruptions to economies and sectors including the banking industry. This study also signifies the avenues for future research that address relevant problems considering the complex data produced in this period.

Author Contributions: Conceptualization, T.-T.D. and T.-T.-Q.T.; Data curation, T.-T.D.; Formal analysis, N.-A.-T.N.; Funding acquisition, C.-N.W.; Investigation, N.-A.-T.N.; Methodology, T.-T.-Q.T.; Project administration, C.-N.W.; Software, T.-T.D. and N.-A.-T.N.; Validation, C.-N.W. and T.-T.D.; Writing-original draft, T.-T.D. and T.-T.-Q.T.; Writing—review and editing, C.-N.W. and N.-A.-T.N. All authors have read and agreed to the published version of the manuscript.

Funding: This research was partly supported by the National Kaohsiung University of Science and Technology, and project number MOST 109-2622-E-992-026 from the Ministry of Sciences and Technology in Taiwan.

Acknowledgments: The authors appreciate the support from the National Kaohsiung University of Science and Technology, Ministry of Sciences and Technology in Taiwan.

Conflicts of Interest: The authors declare no conflict of interest.

\section{References}

1. COVID-19 Hits Profitability of National Banking Sector. Available online: https://customsnews.vn/covid-19-hits-profitabilityof-national-banking-sector-14135.html (accessed on 14 May 2021).

2. Banking Sector Reviews Effects of Covid-19 Pandemic Prepare for Difficult Year. Available online: https://vietnamnews.vn/ economy/business-beat/716434/banking-sector-reviews-effects-of-covid-19-pandemic-prepare-for-difficult-year.html (accessed on 14 May 2021).

3. Batten, J.A.; Vo, X.V. Determinants of Bank Profitability-Evidence from Vietnam. Emerg. Markets Financ. Trade 2019, 55, 1417-1428. [CrossRef]

4. Assaf, A.G.; Berger, A.N.; Roman, R.A.; Tsionas, M.G. Does efficiency help banks survive and thrive during financial crises? J. Bank. Financ. 2019, 106, 445-470. [CrossRef]

5. Paradi, J.C.; Zhu, H. A survey on bank branch efficiency and performance research with data envelopment analysis. Omega 2013, 41, 61-79. [CrossRef]

6. Avkiran, N.K.; Cai, L. Identifying distress among banks prior to a major crisis using non-oriented super-SBM. Ann. Oper. Res. 2014, 217, 31-53. [CrossRef]

7. Avkiran, N.K. An illustration of dynamic network DEA in commercial banking including robustness tests. Omega 2015, 55, 141-150. [CrossRef]

8. Mohtashami, A.; Ghiasvand, B.M. Z-ERM DEA integrated approach for evaluation of banks \& financial institutes in stock exchange. Expert Syst. Appl. 2020, 147, 113218. 
9. Dang-Thanh, N. Measuring the performance of the banking system: Case of Vietnam (1990-2010). J. Appl. Financ. Bank. 2012, 2, 289-312.

10. Cuong, D.X.; Hien, H.T.; Long, T. Multi-Criteria Decision-Making Model Evaluating the Performance of Vietnamese Commercial Banks. Int. J. Financ. Res. 2018, 9, 132-141. [CrossRef]

11. Tlig, H.; Hamed, A. Assessing the Efficiency of commercial Tunisian Banks using Fuzzy Data Envelopment Analysis. J. Data Envel. Anal. Decis. Sci. 2017, 2, 14-27. [CrossRef]

12. Banker, R.D.; Chang, H.; Lee, S.Y. Differential impact of Korean banking system reforms on bank productivity. J. Bank. Financ. 2010, 34, 1450-1460. [CrossRef]

13. Paradi, J.C.; Sherman, H.D.; Tam, F.K. Bank branch benchmarking with quality as a component. In Data Envelopment Analysis in the Financial Services Industry; Springer: Cham, Switzerland, 2018; pp. 159-184.

14. Avkiran, N.K. Measuring the systemic risk of regional banks in Japan with PLS-SEM. Theor. Econ. Lett. 2018, 8, 2024. [CrossRef]

15. Dincer, H.; Hacioglu, Ü.; Celik, I.E. The Game Theory and Reflections on Competitive Strategies in the Banking Sector. In Managerial Issues in Finance and Banking; Springer: Cham, Switzerland, 2014; pp. 145-153.

16. Dahlstrom, R.; Nygaard, A.; Kimasheva, M.; Ulvnes, A.M. How to recover trust in the banking industry? A game theory approach to empirical analyses of bank and corporate customer relationships. Int. J. Bank Mark. 2014, 32, 268-278. [CrossRef]

17. Khanizad, R.; Montazer, G. Participation against competition in banking markets based on cooperative game theory. J. Financ. Data Sci. 2018, 4, 16-28. [CrossRef]

18. Panjaitan, A. Application of Game Theory in Determining the Optimum Marketing Mix Strategy in Banking Companies. Int. J. Basic Appl. Sci. 2020, 9, 53-57.

19. Zandi, F.; Tavana, M.; O'Connor, A. A strategic cooperative game-theoretic model for market segmentation with application to banking in emerging economies. Technol. Econ. Dev. Econ. 2012, 18, 389-423. [CrossRef]

20. Wang, C.N.; Tsai, T.T.; Hsu, H.P.; Nguyen, L.H. Performance evaluation of major Asian airline companies using DEA window model and grey theory. Sustainability 2019, 11, 2701. [CrossRef]

21. Wang, C.N.; Tibo, H.; Duong, D.H. Renewable Energy Utilization Analysis of Highly and Newly Industrialized Countries Using an Undesirable Output Model. Energies 2020, 13, 2629. [CrossRef]

22. Novickyte, L.; Droždz, J. Measuring the efficiency in the Lithuanian banking sector: The DEA application. Int. J. Financ. Stud. 2018, 6, 37. [CrossRef]

23. Xu, T.; You, J.; Shao, Y. Efficiency of China's Listed Securities Companies: Estimation through a DEA-Based Method. Mathematics 2020, 8, 589. [CrossRef]

24. Wang, C.N.; Hsu, H.P.; Wang, Y.H.; Nguyen, T.T. Eco-Efficiency Assessment for Some European Countries Using Slacks-Based Measure Data Envelopment Analysis. Appl. Sci. 2020, 10, 1760. [CrossRef]

25. Liu, F.H.F.; Wang, P.H. DEA Malmquist productivity measure: Taiwanese semiconductor companies. Int. J. Prod. Econ. 2008, 112, 367-379. [CrossRef]

26. Estache, A.; de la Fe, B.T.; Trujillo, L. Sources of efficiency gains in port reform: A DEA decomposition of a Malmquist TFP index for Mexico. Util. Policy 2004, 12, 221-230. [CrossRef]

27. Odeck, J. Assessing the relative efficiency and productivity growth of vehicle inspection services: An application of DEA and Malmquist indices. Eur. J. Oper. Res. 2000, 126, 501-514. [CrossRef]

28. Huang, J.; Du, D.; Hao, Y. The driving forces of the change in China's energy intensity: An empirical research using DEAMalmquist and spatial panel estimations. Econ. Model. 2017, 65, 41-50. [CrossRef]

29. Chung, S.H.; Lee, A.H.I.; Kang, H.Y.; Lai, C.W. A DEA window analysis on the product family mix selection for a semiconductor fabricator. Expert Syst. Appl. 2008, 35, 379-388. [CrossRef]

30. Vlontzos, G.; Pardalos, P.M. Assess and prognosticate greenhouse gas emissions from agricultural production of EU countries, by implementing, DEA Window analysis and artificial neural networks. Renew. Sustain. Energy Rev. 2017, 76, 155-162. [CrossRef]

31. Halkos, G.E.; Tzeremes, N.G. Exploring the existence of Kuznets curve in countries' environmental efficiency using DEA window analysis. Ecol. Econ. 2009, 68, 2168-2176. [CrossRef]

32. Ǩepková, I. Efficiency of the Czech banking sector employing the DEA window analysis approach. Procedia Econ. Financ. 2014, 12, 587-596. [CrossRef]

33. Le, T.N.; Wang, C.N. The integrated approach for sustainable performance evaluation in value chain of Vietnam textile and apparel industry. Sustainability 2017, 9, 477. [CrossRef]

34. Wang, C.-N.; Nguyen, N.-A.-T.; Fu, H.-P.; Hsu, H.-P.; Dang, T.-T. Efficiency Assessment of Seaport Terminal Operators Using DEA Malmquist and Epsilon-Based Measure Models. Axioms 2021, 10, 48. [CrossRef]

35. Charnes, A.; Cooper, W.W.; Rhodes, E. Measuring the efficiency of decision-making units. Eur. J. Oper. Res. 1979, 2, 429-444. [CrossRef]

36. Wang, C.-N.; Dang, T.-T.; Nguyen, N.-A.-T.; Le, T.-T.-H. Supporting Better Decision-Making: A Combined Grey Model and Data Envelopment Analysis for Efficiency Evaluation in E-Commerce Marketplaces. Sustainability 2020, 12, 10385. [CrossRef]

37. Jablonsky, J.; Fiala, P.; Smirlis, Y.; Despotis, D.K. DEA with interval data: An illustration using the evaluation of branches of a Czech bank. Cent. Eur. J. Oper. Res. 2004, 12, 323.

38. Emrouznejad, A.; Anouze, A.L. Data envelopment analysis with classification and regression tree-A case of banking efficiency. Expert Syst. 2010, 27, 231-246. [CrossRef] 
39. Lin, T.Y.; Chiu, S.H. Using independent component analysis and network DEA to improve bank performance evaluation. Econ. Model. 2013, 32, 608-616. [CrossRef]

40. Fujii, H.; Managi, S.; Matousek, R. Indian bank efficiency and productivity changes with undesirable outputs: A disaggregated approach. J. Bank. Financ. 2014, 38, 41-50. [CrossRef]

41. Wang, K.; Huang, W.; Wu, J.; Liu, Y.N. Efficiency measures of the Chinese commercial banking system using an additive two-stage DEA. Omega 2014, 44, 5-20. [CrossRef]

42. Wanke, P.; Barros, C.P.; Emrouznejad, A. Assessing productive efficiency of banks using integrated Fuzzy-DEA and bootstrapping: A case of Mozambican banks. Eur. J. Oper. Res. 2016, 249, 378-389. [CrossRef]

43. Mahmoudabadi, M.Z.; Emrouznejad, A. Comprehensive performance evaluation of banking branches: A three-stage slacks-based measure (SBM) data envelopment analysis. Int. Rev. Econ. Financ. 2019, 64, 359-376. [CrossRef]

44. Yu, M.M.; Lin, C.I.; Chen, K.C.; Chen, L.H. Measuring Taiwanese bank performance: A two-system dynamic network data envelopment analysis approach. Omega 2021, 98, 102145. [CrossRef]

45. Sáez-Fernández, F.J.; Picazo-Tadeo, A.J.; Jiménez-Hernández, I. Performance and risk in the Brazilian banking industry. Heliyon 2021, 7, e06524. [CrossRef] [PubMed]

46. Wang, C.-N.; Nguyen, T.-L.; Dang, T.-T. Analyzing Operational Efficiency in Real Estate Companies: An Application of GM (1,1) and DEA Malmquist Model. Mathematics 2021, 9, 202. [CrossRef]

47. Wang, C.-N.; Nguyen, T.-L.; Dang, T.-T.; Bui, T.-H. Performance Evaluation of Fishery Enterprises Using Data Envelopment Analysis-A Malmquist Model. Mathematics 2021, 9, 469. [CrossRef]

48. Charnes, A.; Clark, C.T.; Cooper, W.W.; Golany, B. A Developmental Study of Data Envelopment Analysis in Measuring the Efficiency of Maintenance Units in the U.S. Air Forces. Ann. Oper. Res. 1985, 2, 95-112. [CrossRef]

49. Yue, P. Data Envelopment Analysis and Commercial Bank Performance: A Primer with Applications to Missouri Banks. Fed. Reserve Bank St. Louis Rev. 1992, 74, 31-45. [CrossRef]

50. Charnes, A.; Cooper, W.W.; Lewin, A.Y.; Seiford, L.M. Data Envelopment Analysis: Theory, Methodology and Applications; Springer: New York, NY, USA, 1995.

51. Vietnam Online Stock Market. Available online: http:/ / vietstock.vn/ (accessed on 18 June 2020).

52. VPBank in Sustainable Development Strategy. Available online: https://tuoitre.vn/vpbank-duy-tri-tang-truong-ben-vung-2020 0717151111649.htm (accessed on 1 June 2021).

53. Top 10 Vietnamese Commercial Banks in 2020. Available online: https://vietnamnet.vn/vn/kinh-doanh/vef/top-10-ngan-hangthuong-mai-viet-nam-uy-tin-nam-2020-657568.html (accessed on 4 June 2021).

54. Vietnamese Commercial Banks in COVID-19. Available online: http://tapchinganhang.gov.vn/thach-thuc-cho-cac-ngan-hangthuong-mai-trong-va-sau-dich-covid-19.htm?fbclid=IwAR3eK8PKY12PO715yjGgMThAsW7DRXnEyUgUQ52tPGgkjJQa9 9BfuZLpQtY (accessed on 1 June 2021). 